\title{
A journey through the Corynebacterium pseudotuberculosis proteome promotes insights into its functional genome
}

\author{
Wanderson Marques da Silva ${ }^{1}$, Nubia Seyffert ${ }^{2}$, Artur Silva $^{3}$, Vasco Azevedo ${ }^{\text {Corresp. } 4}$ \\ 1 Institute of Agrobiotechnology and Molecular Biology - (INTA/CONICET), National Council for Scientific and Technical Research, Hurlingham, Buenos \\ Aires, Argentina \\ 2 Institute of Health Sciences, Federal University of Bahia, Salvador, Bahia, Brazil \\ 3 Laboratory of Genomics and Bioinformatics, Center of Genomics and Systems Biology, Institute of Biological Sciences, Federal University of Para, Belém, \\ Pará, Brazil \\ 4 Genetics, Ecology and Evolution, Federal University of Minas Gerais, Belo Horizonte, Minas Gerais, Brazil \\ Corresponding Author: Vasco Azevedo \\ Email address: vascoariston@gmail.com
}

Background: Corynebacterium pseudotuberculosis is a Gram-positive facultative intracellular pathogen and the etiologic agent of illnesses like caseous lymphadenitis in small ruminants, mastitis in dairy cattle, ulcerative lymphangitis in equines, and oedematous skin disease in buffalos. With the growing advance in high-throughput technologies, genomic studies have been carried out to explore the molecular basis of its virulence and pathogenicity. However, data large-scale functional genomics studies are necessary to complement genomics data and better understating the molecular basis of a given organism. Here we summarize, MS-based proteomics techniques and bioinformatics tools incorporated in genomic functional studies of $C$. pseudotuberculosis to discover the different patterns of protein modulation under distinct environmental conditions, and antigenic and drugs targets. Methodology: in this study was performed an extensive search in Web science of original and relevant articles related to methods, strategy, technology, approaches, and bioinformatics tools focused on the functional study of the genome of $C$. pseudotuberculosis at the protein level. Results: here, we highlight the use of proteomics for understating several aspects of the physiology and pathogenesis of $C$. pseudotuberculosis at the protein level. The implementation and use of protocols, strategies, and proteomics approach to characterize the different subcellular fractions of the proteome of this pathogen. In addition, we have discussed the immunoproteomics, immunoinformatics and genetic tools employed to identify targets for immunoassays, drugs, and vaccines against C. pseudotuberculosis infection. Conclusion: in this review, we showed that the combination of proteomics and bioinformatics studies is a suitable strategy to elucidate the functional aspects of the C. pseudotuberculosis genome. Together, all information generated from these proteomics studies allowed expanding our 
knowledge about factors related to the pathophysiology of $C$. pseudotuberculosis. 


\section{A journey through the Corynebacterium}

\section{2 pseudotuberculosis proteome promotes insights into its}

\section{3 functional genome}

4

5 Wanderson Marques Da Silva ${ }^{1}$, Núbia Seyffert ${ }^{2}$, Arthur Silva ${ }^{3}$, Vasco Azevedo ${ }^{4}$

71 - Institute of Agrobiotechnology and Molecular Biology - (INTA/CONICET), National

8 Council for Scientific and Technical Research, Hurlingham, Buenos Aires, Argentina.

92 - Institute of Health Sciences, Federal University of Bahia, Salvador, Bahia, Brazil.

3 - Laboratory of Genomics and Bioinformatics, Center of Genomics and Systems Biology, Institute of Biological Sciences, Federal University of Para, Belém, Pará, Brazi.

Horizonte, Minas Gerais, Brazil.

\section{Corresponding author:}

Vasco Azevedo ${ }^{4}$

Av. Antonio Carlos, 6627. Pampulha, Belo Horizonte, Minas Gerais, CP 486, Brazil

Email address: vascoariston@gmail.com

\section{ABSTRACT}

Background: Corynebacterium pseudotuberculosis is a Gram-positive facultative intracellular pathogen and the etiologic agent of illnesses like caseous lymphadenitis in small ruminants, mastitis in dairy cattle, ulcerative lymphangitis in equines, and oedematous skin disease in 
24 buffalos. With the growing advance in high-throughput technologies, genomic studies have been

25 carried out to explore the molecular basis of its virulence and pathogenicity. However, data large-scale functional genomics studies are necessary to complement genomics data and better understating the molecular basis of a given organism. Here we summarize, MS-based proteomics techniques and bioinformatics tools incorporated in genomic functional studies of $C$.

pseudotuberculosis to discover the different patterns of protein modulation under distinct environmental conditions, and antigenic and drugs targets. Methodology: in this study was performed an extensive search in Web science of original and relevant articles related to methods, strategy, technology, approaches, and bioinformatics tools focused on the functional study of the genome of $C$. pseudotuberculosis at the protein level. Results: here, we highlight the use of proteomics for understating several aspects of the physiology and pathogenesis of $C$. pseudotuberculosis at the protein level. The implementation and use of protocols, strategies, and proteomics approach to characterize the different subcellular fractions of the proteome of this pathogen. In addition, we have discussed the immunoproteomics, immunoinformatics and genetic tools employed to identify targets for immunoassays, drugs, and vaccines against $C$. pseudotuberculosis infection. Conclusion: we showed that the combination of proteomics and bioinformatics studies is a suitable strategy to elucidate the functional aspects of the $C$. pseudotuberculosis genome. Together, all information generated from these proteomics studies allowed expanding our knowledge about factors related to the pathophysiology of $C$. pseudotuberculosis.

\section{INTRODUCTION}

Corynebacterium pseudotuberculosis is a Gram-positive facultative intracellular pathogen belonging to the CMNR (Corynebacterium-Mycobacterium-Nocardia-Rhodococcus) group 
47 (Barksdale, 1970). This supra-generic group of Actinomycetes exhibits a specific cell wall

48

49 composed of peptidoglycan, arabinogalactan, and mycolic acids and a high chromosomal $\mathrm{G}+\mathrm{C}$ content (Burkovski, 2013; Ventura et al., 2007). C. pseudotuberculosis may be distinguished into two biovars according to nitrate reductase production: biovar ovis (nitrate negative) and biovar equi (nitrate positive) (Biberstein et al., 1971; Dorella et al., 2006). Biovar ovis strains cause caseous lymphadenitis in small ruminants (Williamson, 2001; Baird \& Fontaine, 2007) and mastitis mainly in dairy cattle (Shpigel et al., 1993). On the other hand, biovar equi strains cause ulcerative lymphangitis (Britz et al., 2014; Haas et al., 2017) and abscesses in the internal organs of the equines and oedematous skin disease in buffalos (Selim, 2001).

The infection by this pathogen is globally reported and causes significant economic losses affecting meat, wool, and milk production (Haas et al., 2017; Kumar et al., 2012; Windsor, 2011). The pathogenic process of C. pseudotuberculosis begins with colonization and replication within lymph nodes in the initial site of infection. In this initial step occurs the pyogranuloma formation. Due to its ability to survive and multiply within the macrophage phagosome, this pathogen begins a new cycle of bacterial replication. In this second cycle occurs death of the host cell and subsequent release and dissemination of bacterial via the lymphatic or circulatory system, allowing the pathogen to infect visceral organs and lymph nodes, where it ultimately induces lesion formation (Batey, 1986; Pépin et al., 1994; Stefańska et al., 2010).

Regarding to virulence factors that contribute to C. pseudotuberculosis pathogenesis is phospholipase D (PLD) described as major virulence factor of this bacterium, which is involved in the dissemination of C. pseudotuberculosis from the site initial of infection to the lymph nodes (McNamara et al., 1994) and, reduction of the viability ovine neutrophils (Yozwiak \& Songer, 1993) and macrophage (McKean et al., 2007). In addition, others determinants of virulence have 
70

71

72

been described as $f a g A B C D$ operon (Billington et al., 2002) and CiuA siderophore (Ribeiro et al., 2014), both associated to iron uptake, cell wall components (Muckle \& Gyles, 1983), CP40 serine protease (Walker et al., 1994; Wilson et al., 1995), PhoP regulator of the PhoPR system two-component system (Tiwari et al., 2014), and OppD related to adherence and infection macrophages (Moraes et al., 2014).

The availability of whole-genome sequences of several C. pseudotuberculosis strains has provided information about the molecular basis on its dynamic physiology as well as pathogenesis. Upon the genome sequencing of FCR41 strain, Trost et al. (2010) proposed the following genes like putative virulence factors: $n a n H$ (neuraminidase $\mathrm{H}$ ), rpfI (resuscitationpromoting factor interacting protein), $r p f A$ and $r p f B$ (resuscitation-promoting factors $\mathrm{A}$ and B), nor (nitric oxide reductase), $d t s R 1$ (acetyl-CoA carboxylase $\beta$-subunit involved in fatty acid synthesis), dtsR2 and accD3 (acetyl-CoA carboxylase, beta subunit, involved in the biosynthesis of mycolic acid) and $\operatorname{spaC}$ (adhsin component of adhesin) and nrpS1 and nrpS2 (nonribosomal peptide synthetase 1 and 2). Currently, 124 genomes of $C$. pseudotuberculosis are publicly available at NCBI repositories. A number of these genomic studies have been carried out by our research group. These collections of genome data have been demonstrated across several $C$. pseudotuberculosis, presenting an average genome size of approximately $2,3 \mathrm{Mb}$, with a coregenome having approximately 768 genes and 2,795 belonging to the accessory genome (Araújo et al., 2019). In addition a pan-genomic analysis showed that pathogenic corynebacteria exhibited a close relationship and a clonal-like behavior among isolates of $C$. pseudotuberculosis (Soares et al., 2013a). On the other hand, through these genomic data, the C. pseudotuberculosis proteome was predicted with an average of approximately 2,098 proteins (Ruiz et al., 2011;

Santos et al., 2012). 
94 the protein level, in microbiology, proteomics studies have contributed to broadening our

95

knowledge about microbial adaptation in different types of environmental stress, pathogenesis, host-pathogen interaction, and microbial meta-proteomics (Cordwell, Nouwens \& Walsh, 2001; Schmidt \& Völker, 2011; Otto et al., 2012; Broadbent et al., 2016). In this context, proteomics studies have been performing aiming to characterize the $C$. pseudotuberculosis proteome (Table 1). The first studies of the proteome of C. pseudotuberculosis were based on one-dimensional sodium dodecyl sulphate polyacrylamide gel electrophoresis (SDS-PAGE) and immunoblotting (Ellis et al., 1991; Muckle et al., 1992; Braithwaite et al., 1993). The main objective of these studies is to describe the protein band patterns expressed by various strains and identify targets for the development of immunodiagnostics and vaccine targets to combat diseases caused by this pathogen. Mass spectrometry (MS)-based proteomics promotes a high level of detection and identification of proteins. Currently, researchers employ MS techniques such as two-dimensional gel electrophoresis (2-DE), liquid chromatography coupled to mass spectrometry (LC-MS), and multidimensional protein identification technology (MudPIT) that combines several twodimensional chromatographic methodologies and MS to characterize and quantify the proteome of C. pseudotuberculosis.

Once, the last work which provides information about proteomic studies carried out with C. pseudotuberculosis was written by Dorella \& cols in 2013. This work aims to promote an update regarding the latest advances obtained on the functional genome of C.pseudotuberculosis through proteomic studies. In addition, this study will provide an overview of immunoproteomics, bioinformatic, and genetic tool used to explore the proteome of this pathogen to identify potential targets for the development of vaccines and immunodiagnostic 
116 methods against illnesses caused by this pathogen. This review will surely interest other research

117 teams working on other pathogens. Furthermore, our findings are of considerable interest to

118 those who work on the identification of bacterial antigenic targets, pathogenesis, functional

119 genomics, and the adaptive strategies of pathogenic bacteria.

\section{Survey Methodology}

121 Extensive literature research was conducted using the following electronic databases: Pubmed,

122 Science Direct, Google Scholar, and Scopus. The keyword combinations such as: $C$.

123 pseudotuberculosis and proteomic, C. pseudotuberculosis and proteome, C. pseudotuberculosis

124 and bioinformatics, C. pseudotuberculosis and proteins, C. pseudotuberculosis and drugs, $C$.

125 pseudotuberculosis and functional genomics, bacterial and exoproteome, bacterial and

126 surfaceome, C. pseudotuberculosis and antigens, C. pseudotuberculosis and vaccine, bacterial

127 and proteomic, C. pseudotuberculosis and genomics, C. pseudotuberculosis and hypothetical

128 proteins, bacterial and moonlight proteins were utilized to build literature review. All articles

129 were extensively studied to be utilized as references in the present review article.

130 Strategies and proteomic approach utilized to characterize the . pseudotuberculosis

131 exoproteome

132 Bacteria can release proteins across external membranes to the extracellular milieu through

133 different exportation and secretion pathways. Extracellular proteins are considered essential

134 elements of physiology, pathogenicity, and virulence bacterial. These proteins are related to

135 distinct processes such as adhesion and invasion to host cells, damage to host tissues, resistance

136 to environmental stress, nutrient acquisition and subversion of the host's immune response

137 (Desvaux et al., 2009; Galán \& Waksman, 2018; Weber \& Faris, 2018). On the other hand, some

Peer] reviewing PDF | (2021:05:61050:2:0:NEW 25 Sep 2021) 
138 studies showed that exoproteins to be the potential target for the development of drugs (Maffei,

139 Francetic \& Subtil, 2017; Galán and Waksman, 2018). Thus, the characterization of the bacterial

140 proteins present in the extracellular milieu, i.e. exoproteome (Desvaux et al., 2009), besides

141 promoting knowledge about physiology and bacterial virulence, may represent targets important

142 for drug and vaccine development as well as immunodiagnostic tests.

As described above, during the first studies, different groups used techniques as one-

144 dimensional SDS-PAGE and immunoblot to characterize the extracellular proteins produced

by C. pseudotuberculosis (Ellis et al., 1991; Braithwaite et al., 1993). These studies allowed the

146 identification only of the molecular mass of the proteins. Moreover, these extracellular proteins

147 come from bacterial growth in bacterial culture media such as brain-heart infusion (BHI) or

148 Tryptone, which are culture media extremely rich in proteins. Then, to eliminate the presence of

149 exogenous proteins from complex media in the bacterial culture supernatant, Moura-Costa et al.

150 (2002) has developed a chemically-defined medium (CDM) for C. pseudotuberculosis culture.

151 Interestingly, the bacterial growth in this medium allowed the production of extracellular

152 proteins with high molecular weight (showed by SDS-PAGE) that are not produced when the

153 bacterium was grown in the BHI medium (Paule et al., 2004a). Currently, no work has analyzed

154 which components of this medium are responsible for inducing these proteins. Another study

155 shows that this extracellular fraction from bacterial grown in CDM recognized the IgG of

156 experimentally infected goats in an ELISA assay; in addition, the use of these extracellular

157 proteins in an interferon- $\gamma(\mathrm{IFN}-\gamma)$ assay provided a more specific response when compared to

158 the use of proteins obtained from bacterial whole-cell sonicated (Paule et al., 2003). These

159 results demonstrate that in addition to being a medium is suitable for the growth of $C$.

160 pseudotuberculosis; CDM induces antigenic proteins of this pathogen. 
pseudotuberculosis, a three-phase partitioning protocol (TPP) was standardized (Paule et al., 2004b). Studies have been demonstrated that the TPP method is a powerful technique for extraction, separation, and purification of bioactive molecules (Dennison \& Lovrien, 1997; Yan et al., 2018; Wang et al., 2019). In the TPP method, the proteins are precipitated between the aqueous phase (upper phase) generated for the ammonium sulfate and the organic phase (lower phase), which contain $n$-butanol (Dennison \& Lovrien, 1997). During the standardization of the TPP, Paule et al. (2004b) showed that lowering the $\mathrm{pH}$ of the culture medium supernatant before precipitation with $30 \%$ ammonium sulfate concentration promotes an increased qualitative extraction. This technique allowed the detection of extracellular immunoreactive proteins of low $(16 \mathrm{kDa})$ and high $(125 \mathrm{kDa})$ molecular weights not detected by other studies that used only the ammonium sulfate precipitation method (Ellis et al., 1991; Braithwaite et al., 1993; Paule et al., 2003).. On the other hand, these precipitated proteins from the TPP technique were useful in detect sheep and goats with caseous lymphadenitis in an IFN- $\gamma$ assay (Rebouças et al., 2011). to obtain extracellular proteins; the followings studies of the extracellular proteins of C. pseudotuberculosis combined CDM, TPP, and MS-based proteomics. These studies were based on both gel-based and gel-free (Figure 1). Gel-based analyses were carried out through 2-DE and 2D-DIGE techniques following mass spectrometry using MALDI-TOF/TOFMS/MS (Silva et al., 2013a; 2013b). However, to suppress some limitations of the gel-based analysis, such as sample amount, quantitative statistical power, and depth of proteome coverage; our group adopts the LC-MSE approach to characterize the exoproteome of C. pseudotuberculosis (Pacheco et al., 2011; Pacheco et al., 2012; Silva et al., 2017a; Silva et al., 2017b). This versatile high- 
184 throughput method based in label-free quantification has the advantage of having a high

185

186

187

188

189

190

191

192

193

194

195

196

197

198

199

200

201

202

203

204

205

206

sensitivity, which makes it possible to increase the coverage level of the proteome (Silva et al., 2005). To complement these proteomic analyses, Santos et al. (2012) established a pipeline for in silico prediction of the subcellular localization of the C. pseudotuberculosis proteome. This pipeline includes the following software packages: (i) SurfG+ (Barinov et al., 2009) being the leading tool responsible for subcellular classifications in cytoplasmic (CYT), membrane (MEM), potentially surface exposed (PSE) and secreted (SEC), (ii) TatP 1.0 (Bendtsen et al., 2005a), (iii) SecretomeP 2.0, (Bendtsen et al., 2005b) and (iv) NclassG+ (Restrepo-Montoya et al., 2011) (Currently, NclassG+ tool is not available), with the latter three software's allowing the nonclassical secretion prediction.

In a pioneer study, using TPP-LC/MSE approach (combination between TPP method and LC/MSE proteomic), Pacheco et al., 2011, carry out a comparative proteomic analysis between two C. pseudotuberculosis reference strains: low virulent strain 1002_ovis (isolated from goat in Brazil) (Ribeiro et al., 1991; Meyer et al., 2002) and high virulent strain C231_ovis (isolated from sheep in Australia) (Simmons et al., 1998) during exponential growth in CDM. This proteomic analysis identified 70 proteins in 1002_ovis, 67 proteins in C231_ovis and 44 proteins common between both strains. This study comparative allows the characterization of 93 different extracellular proteins of C. pseudotuberculosis, among them, $75 \%$ were predicted with exportation signals, showing the high capacity this approach adopted by the authors in identify exported proteins. Comparative analysis identified virulence factors such as PLD exotoxin, CiuA siderophore, FagD siderophore, and Cp40 serine protease only in the extracellular proteome of C231_ovis. In turn, mainly proteases and unknown function proteins compose the exoproteome exclusive of 1002_ovis. Further, the following moonlight proteins: Elongation factor Tu, 
207 Elongation factor Ts, co-chaperonin GroES, Peroxiredoxin, and Phosphoglyceromutase are

208 present in the exoproteome exclusive of this strain. According to the authors, the absence of PDL

209 exotoxin in the extracellular proteome of the strain 1002_ovis would be related to its low

210 virulence profile or the growth condition utilized in this study. A study showed that PLD

211 induction occurs under specific environmental conditions (McKean et al., 2007).

Silva et al. (2013) also observed the absence of both PLD exotoxin and CP40 in

1002_ovis exoproteome. . In this study, the authors compared the exoproteome of 1002_ovis and

214 C231_ovis during the stationary phase in CDM using 2-DE. Comparative analysis showed

215 differences between the protein maps of the strains. After MALDI-TOF-MS/MS, 55 and 45

216 proteins were detected in 1002_ovis and C231_ovis, respectively. In the exclusive proteome of

217 C231_ovis was detected the PLD exotoxin and CP40. In turn, in the exclusive exoproteome of

218 1002_ovis was detected the DsbG protein, a strain-specific protein. In addition, in this study, the

219 authors reported 11 proteins (GroEL, DnaK, Elongation factor P, GAPDH, ABC-type

220 transporter, Carbonic anhydrase, Manganese superoxide dismutase and three unknown function

221 proteins) that were not previously detected in the study conducted by Pacheco et al.

222 (2011). Using the 2D-DIGE technique, Silva et al. (2013b) identified seventeen extracellular

223 spots differentially produced between the 1002_ovis and C231_ovis (Silva et al., 2013b). These

224 differentially induced proteins are related to energy production, cell wall, proteases, and

225 unknown function proteins. Among them was detected the Lysozyme M1 that was not detected

226 in other studies (Pacheco et al., 2011; Silva et al., 2013a). Together, these three proteomic

227 studies (Pacheco et al., 2011; Silva et al., 2013a, Silva et al., 2013b) showed differences between

228 the exoproteome of 1002_ovis and C231_ovis. In addition, these studies identified 105 different

229 extracellular proteins of C. pseudotuberculosis. LC/MSE identified 57\% (60 proteins) of the 
230 proteins due to the high sensibility of this method; $33 \%$ both gel-free and gel-based, and $12 \%$

231 only by gel-based approaches.

In another study, Pacheco et al. (2012) compared the exoproteomes of the sigE mutant

233

234

235

236

237 and its parental strain 1002_ovis upon nitric oxide (NO) exposition. Various pathogens often find this reactive nitrogen species (RNS) inside macrophages (Ferrari et al., 2011). In this study, the authors showed that the sigma $(\sigma)$ factor $\sigma^{\mathrm{E}}$ is required in the resistance process of $C$. pseudotuberculosis to nitric oxide and peroxide stress (Pacheco et al., 2012). According to proteomic analysis the proteins thiol peroxidase, Glyoxalase/dioxygenase and ABC-type metal ion transport system are induced in wild-type strain upon NO-exposition. In the sigE mutant, the following proteins are in their exclusive exoproteome: four ABC-transporters, Alkyl hydroperoxide reductase subunit C, DnaK, Nitrite reductase periplasmic cytochrome c552, Periplasmic zinc-binding protein troA, Penicillin-binding protein A, Phosphocarrier protein $\mathrm{HPr}$, Serine/threonine-protein kinase, Fructose-bisphosphate aldolase, and GAPDH.

The proteomic analysis of the culture supernatant of 1002_ovis (Silva et al., 2017a) and 258_equi (Silva et al., 2017b) strains isolated from mice spleen identified proteins that might play a role in the physiology of $C$. pseudotuberculosis. In these studies, mice have been experimentally infected and recovered strains submitted to proteomic analysis. The proteomic screening in 1002_ovis was carried out by combining the LC-MS ${ }^{\mathrm{E}}$ and 2-DE/MALDI-TOF/TOFMS/MS (Silva et al., 2017a). Interestingly, the virulence factors CP40 and PLD exotoxin are present in the exoproteome of recovered condition. These virulence factors had not been identified in previous studies of the exoproteome of this strain; when cultivated in laboratory standard conditions (Pacheco et al., 2011; Silva et al., 2013a; Silva et al., 2013b). This study showed that the induction of PLD exotoxin in strain 1002_ovis is influenced by environmental 
253 conditions. On the other hand, the 258_equi exoproteome was characterized utilizing only LC-

$254 \mathrm{MS}^{\mathrm{E}}$. From this quantitative proteomic analysis, the more induced proteins after the recuperation

255 process were related mainly to iron-acquisition such as CiuA, FhuD, FagC, HmuT, HmuV, and

256 HtaA (Silva et al., 2017b). Studies have shown that CiuA (Ribeiro et al., 2014) and proteins from

257 fag operon (Billington et al., 2002) are involved in the C. pseudotuberculosis pathogenesis.

258 Moreover, several studies showed that proteins related to iron-uptake are required for bacterial

259 pathogenesis (Schaible \& Kaufmann, 2004; Cassat \& Skaar, 2013; Sheldon et al., 2016). These

260 results suggest that proteins related to iron-uptake can play an important role in the pathogenesis

261 of 258 equi.

\section{Membrane-associated proteins of $C$. pseudotuberculosis}

263 The bacterial cell envelope is a structure that corresponds to the cell surface, which protects

264 bacterial cells and further mediates different types of interactions between bacteria and the

265 environment (Rajagopal \& Walker, 2017). In Gram-positive bacteria, the cell envelope is

266 composed of two structures (i) cytoplasmic membrane (CM) and (ii) cell wall (CW). The CM is

267 a selectively permeable barrier formed by a phospholipid bilayer composed of lipids, proteins,

268 and carbohydrates. The proteins embedded in the CM can be either integral or anchored to the

269 membrane. In turn, the $\mathrm{CW}$ is a structure that surrounds the cytoplasmic membrane and provides

270 bacterial cell protection against mechanical stresses and osmotic lysis. The leading constituents

271 of the $\mathrm{CW}$ are peptidoglycan, lipoteichoic acids, polysaccharides, glycopolymers, and proteins.

272 The proteins found in the cell wall are covalently bound or bound through weak interactions

273 (Weidenmaier and Peschel, 2008; Rajagopal \& Walker, 2017; Desvaux, Candela \& Serror,

274 2018). Thus, these sets of molecules that comprise the bacterial cell surface form the "bacterial

275 surfaceome" and comprehensive analysis of the proteins present in the surfaceome is referred to 
276 as the "proteosurfaceome" (Desvaux, Candela \& Serror 2018). In bacterial pathogens, the

277 surface proteins have a key role in the interplay between the bacteria and their host (Kline et al.,

278 2009; Hammerschmidt, Rohde \& Preissner, 2019). isolate (RLC001 isolate) obtained directly from naturally infected sheep lymph nodes. Shaving is a powerful strategy to characterize surface-exposed proteins. In this technique, the treatment of the intact bacterial cells with protease cleaves the proteins, and then the peptide fragments generated are submitted to MS analysis (Rodríguez-Ortega et al., 2006). In this study after MS analysis of the peptide fragments cleaved by trypsin, the authors characterized 89 proteins of $C$. pseudotuberculosis in caseous material related to different biological processes. Interestingly, when this set of proteins was compared with the proteomic profile of C231_ovis growth in culture media, the authors observed that the following proteins: chromosome partitioning protein ParB, Regulatory protein RecX, Protein FadF, Enolase, Fumarate hydratase class II, Argininosuccinate synthase, Sulfurtransferase, Glycerol-3-phosphate dehydrogenase, Aspartatesemialdehyde dehydrogenase, Lipid A biosynthesis lauroyl acyltransferase, Ascorbate-specific permease IIC component UlaA, Purine nucleoside phosphorylase DeoD-type, and Methylmalonyl-CoA carboxyltransferase $12 \mathrm{~S}$ subunit were detected exclusively in the caseous material. In addition, they identified 49 host proteins from infected lymph nodes (Table S.1), among them are important factors related to mainly immune response. et al., 2016). In this study, the authors utilized the following strategy; bacterial growth in culture 
299

300

301

302

303

304

305

306

307

308

309

310

311

312

313

314

315

316

317

318

319

320

medium composed by bovine fetal serum, obtaining of the proteins through an organic solvent enrichment protocol and LC-MS/MS analysis. Upon the MS analysis, the authors identified 116 proteins related to several biological processes. Among them are proteins involved in $C$. pseudotuberculosis pathogenesis, such as CiuA_(Ribeiro et al., 2014) and FagA (Billington et al., 2002). Further are OppA4 and OppCD2 proteins of the operon oppBCDA (oligopeptide permease) involved in the adherence and infection macrophages (Moraes et al., 2014).

\section{Towards the whole-cell lysed proteome of $C$. pseudotuberculosis}

The whole-cell proteomic strategy allows the identification and quantification of thousands of proteins. This strategy promotes a global proteomic analysis of a cell; due to the capacity to identify proteins from different subcellular fractions, which allows discovery and exploration of biological pathways. Thus studies applied the proteomic analysis of whole-cell protein extracts to access a high level of coverage of the global proteome of C. pseudotuberculosis.

Rees et al. (2015b) used both genomic and proteomic comparative analysis to identify the differences among three isolates of $C$. pseudotuberculosis obtained from lymph nodes of naturally infected sheep (field isolates) and reference strain C231_ovis. In this study, the authors utilized two MS-based quantification methods; (i) label-free and (ii) dimethylation labeling based on stable isotope. In this second method, the samples are labeled with heavy (C231_ovis) and light (field isolates) formaldehyde. From this comprehensive proteomic analysis 1.250 and 1.358 proteins were identified in label-free and dimethylation labeling methods, respectively. Although, genomic analysis reveals the presence of SNPs, and the gene presence or absence, among reference strain and field isolates. The proteins that have differential abundance were those conserved across all field isolates and C231_ovis. Among the differentially induced 
321 proteins, eight proteins were more induced in all three field isolates (Pyruvate carboxylase, 5-

322 formyltetrahydrofolate cyclo-ligase, Fructose-1,6-bisphosphatase, Precorrin-3B synthase, Citrate

323 lyase subunit beta-like protein, uncharacterized protein $\mathrm{YcaO}, \mathrm{ABC}$ transporter substrate-binding

324 lipoprotein YvrC, and one hypothetical protein) and four were less induced in all three field

325 isolates (Glutamate ABC transporter domain-containing ATP-binding protein, GluB, FhuD, and

326 PstS). The use of strains recently isolated from natural hosts enabled access to proteins that

327 might be required by this pathogen during the colonization processes.

The comparative analysis between the proteome of 1002_ovis and 258_equi via label-free

329 proteomics characterized, 1.227 and 1.218 proteins para each strain, respectively (Silva et al.,

330 2017c). Despite the quantitative differences observed in the core proteome such as induction of

331 PLD in 258_equi, significant differences are present in the individual proteome of each strain,

332 where strain-specific proteins were detected. The authors reported in the exclusive proteome of

333 1002_ovis a DNA methylase (ORF that codifies this protein is absent in the genome of

334 258_equi) and seven proteins involved in adhesion and motility cell, carbohydrate metabolism,

335 lipid metabolism and unknown function that are annotated like pseudogene in the genome of

336 strain 258_equi. On the other hand, in the exclusive proteome of 258_equi was detected one

337 MoeB protein, two CRISPR-associated proteins, and three proteins with unknown function

338 (Cp258_0076, Cp258_0585, and Cp258_0586) (ORF that codify these proteins is absent in the

339 genome of 1002 ovis). In addition, twenty proteins present in the proteome of 258_equi related

340 to amino acid metabolism, coenzyme metabolism, carbohydrate metabolism, energy metabolism,

341 inorganic ion transport, post-translational modification, intracellular trafficking secretion and

342 vesicular transport and unknown function are annotated like pseudogene in the genome of strain 
343 1002_ovis. These differences observed reports information that can be useful to understand the

344 aspects related to both pathogenesis and physiology of these strains.

Some study has been reported the biofilm formation in C. pseudotuberculosis (Sá et al.,

346 2013; Chandran et al., 2016), this process offers protection during the bacterial growth in a

347 hostile environment and contributes to the pathogen's persistence during the infection process

348 (Costerton et al., 1999). Studies shown that proteins associated to various biological processes

349 are related to biofilm formation (Rani et al., 2018). In this context, De Sá et al. (2021) used label-

350 free proteomics to compare the proteome of biofilm-forming (CAPJ4_ovis) and non-biofilm-

351 forming (CAP3W_ovis) strains of C. pseudotuberculosis isolated from goats. The following

352 proteins: GalT, GlpD, Zwf, and EtfA (metabolism), trehalose corynomycolyl transferase B,

353 CwlM, and D-alanyl-Dalanine carboxypeptidase (cell wall components), and Phet (quorum

354 sensing) were more induced in strain CAPJ4_ovis. These proteins are related to biological

355 pathways required for biofilm formation in prokaryotic organisms/prokaryotes. Thus more

356 studies are necessary to evaluate the role of these proteins in the biofilm formation in $C$.

357 pseudotuberculosis.

In addition to these comparative proteomic studies between strains, the whole-cell extract

of C. pseudotuberculosis has been characterized under stress conditions. From label-free

proteomic analysis using LC/MS ${ }^{\mathrm{E}}$ approach, Silva \& cols (2014) reported the leading group of

proteins utilized by strain 1002_ovis for resistance to oxide nitric. More induced proteins in

stress condition were related to general stress response, cellular metabolism, detoxification,

363 transcriptional regulation, and DNA synthesis and repair. Interestingly, the

364 Glyoxalase/Bleomycin resistance protein/Dioxygenase involved in the detoxification process

365 (Thornalley, 2003; He \& Moran, 2011) was detected as more induced after stress exposition. The 
366

367

368

369

370

371

372

373

374

375

376

377

378

379

380

381

382

383

384

385

386

387

same protein was also detected in the study conducted by Pacheco et al. (2012). According to the

authors, the presence of this protein in both studies suggests that Glyoxalase/Bleomycin

resistance protein/Dioxygenase can play an important physiological role during the $C$.

pseudotuberculosis exposition to nitric oxide.

\section{Identification of antigenic proteins, drugs, and vaccine targets through the $C$.}

pseudotuberculosis proteome

Immunoproteomics includes the use of different proteomic technologies to identify antigenic

peptides and proteins. In turn, immunoinformatics includes studies associated with

immunological knowledge using bioinformatics software. Once cell surface-exposed and

secreted proteins play an essential role in the host-pathogen interaction, these proteins represent a

potential target in the formulation of drugs, biomarkers, and vaccines (Vytvytska et al., 2002;

Falisse-Poirrier et al., 2006; Fulton, Baltat \& Twine, 2019; Raoufi et al., 2020; Oli et al., 2020).

The Serological Proteome Analysis (SERPA) is a powerful immunoproteomic method

often employed to identify immune-reactive proteins. In SERPA analysis, proteins are firstly

resolved by 2-DE, then western blots are performed using reactive sera to detect the

immunoreactive proteins, and finally, these proteins are identified by MS (Klade, 2002; Fulton et

al., 2019). Employing SERPA analysis, Seyffert et al. (2011) identified six immunoreactive

exoproteins (RpfB, NlpC/P60, efflux system protein, SlpA, and one unknown function protein).

This preliminary study combined the serum of goats infected with C. pseudotuberculosis and

extracellular proteins of 1002_ovis. In a second study, Syffert et al. (2014) utilized a pool of

serum from goat and sheep infected by C. pseudotuberculosis and comparative proteomics to

identify immune-reactive proteins. The comparative analysis between the exoproteome of 1002

Peer] reviewing PDF | (2021:05:61050:2:0:NEW 25 Sep 2021) 
388

389

390

391

392

393

394

395

396

397

398

399

400

401

402

403

404

405

406

407

408

409

410

and C231 allowed identifying 13 immunoreactive proteins non-redundant Interestingly, six

immune-reactive exoproteins (Cphp1, Cphp2, Cphp3, Cphp4, Cphp6, and Cphp7) with unknown

functions identified in the core-exoproteome are exclusive of C. pseudotuberculosis. This result

is notary because these specific proteins represent the potential targets to be employed in

diagnostic methods against caseous lymphadenitis (Syffert et al., 2014).

Using a reporter transposon-based system TnFuZ, Dorela et al. (2006) identified 21

mutant strains with an alkaline phosphatase-positive activity that presented transposon insertions in genes that encode exported proteins. This system combines a reporter transposon-based system TnFuZ and the Tn4001 transposable element with the alkaline phosphatase gene (phoZ) from Enterococcus faecalis (Gibson \& Caparon, 2002). Posteriorly, the 21 mutant strains and their T1 parental strain have been employed in a vaccination assay using a murine model (Ribeiro et al., 2014). In this study, mice have been intraperitoneally inoculated. Among all strains evaluated, the strain CZ171053 (a ciuA secreted-siderophore null presented) showed the best protection level (protection level, 80\%) against the challenge with $C$.

pseudotuberculosis MIC-6 a highly virulent wild strain. TnFuZ proved to be a rapid strategy in generating mutant strains (to gene encoding secreted proteins) for their posterior evaluation as candidate vaccines. Galvão et al. (2017) performed immunoscreening in a gene expression library of C. pseudotuberculosis. According to this analysis, the authors identified the following genes $d a k 2, f a g A, f a g B, \mathrm{NlpC} / \mathrm{P} 60$ protein family, and LPxTG putative protein family, as potential targets to immunoassays or vaccine formulations, against caseous lymphadenitis.

The Mature Epitope Density (MED) is an immunoinformatics strategy extremely useful in selecting antigenic targets. This approach determines the epitopes concertation in exported proteins for major histocompatibility complex (MHC) I (Santos et al., 2013). The MED 1.0 
411 Server pipeline (Santos et al., 2013) includes the following bioinformatics tools for predicting

412 subcellular localization: SurfG+ 1.0 (Barinov et al., 2009) and TMHMM (Krogh et al., 2001).

413 Using MED 1.0 Server, Rezende et al. (2016) identified three exoproteins: Cp1002_0126a,

414 Cp1002_0369 (CP01850) and Cp1002_1957 (CP09720) as potential antigenic target. In

415 immunoenzymatic assays, the authors showed that the $\mathrm{rCP} 01850$ recombinant protein presents

416 high values of specificity and sensitivity, than rCP09720 recombinant protein. After this study,

417 Brum et al. (2017) showed that mice immunized with the recombinant CP09720 (rCP09720)

418 associated with aluminum hydroxide adjuvant present protection levels of $58.3 \%$, against the

419 challenged with MIC-6 virulent strain. In another study, the rCP01850 and rCP09720

420 recombinant proteins have been combined individually with recombinant PLD (rPLD) in a

421 vaccination formulation (Silva et al., 2018). In this study, the rCP01850 + PLD formulation

422 presented the best protection level in mice (subcutaneous inoculation route) against the challenge

423 with strain MIC-6. On the other hand, when rCP09720 + rPLD was utilized in ELISA assay

424 using serum samples from sheep with superficial lymph nodes abscesses, this combination

425 demonstrated high sensitivity (97.5\%) and specificity, than rCP01850 + PLD (Silva et al.,

426 2019). More recently, a study showed that one vaccine formulation composed of rCP01850

427 protein and Brazilian red propolis as an adjuvant induces cellular and humoral immune responses

428 (Brilhante Bezerra et al., 2020).

Reverse vaccinology is a concept adopted by the post-genomic era for vaccine targets

430 discovery from genome sequence information of a pathogen (Rappuoli, 2000). However, due to

431 the rapid availability of complete bacterial genomes, this concept has been expanded to pan-

432 genomics reverse vaccinology (Bambini \& Rappuoli, 2009). Using this concept, some studies

433 have utilized reverse vaccinology as a strategy to identify potential vaccine targets inside the 
434 genome of $C$. pseudotuberculosis. The in silico prediction of the pan-exoproteome of five $C$.

435 pseudotuberculosis strains (1002_ovis, C231_ovis, I19_ovis, FRC41_ovis, and PAT10_ovis)

436 identified 306 exported proteins (122 predicted as SEC and 122 predicted as PSE proteins)

437 common among all strains (Santos et al., 2012). This pioneering study allowed for the first time

438 to build a dataset of possible vaccine targets. Soares et al. (2013a) carried out a screen in the

439 genome of three C. pseudotuberculosis strains 1002_ovis, 258_equi, and CIP 52.97_equi. In this

440 study, secreted proteins, PSE proteins, or membrane proteins predicted by SurfG + software

441 (Barinov et al., 2009) were analyzed by the Vaxign software (He, Xiang \& Mobley, 2010),

442 resulting in a total of 49 core-proteins with antigenic properties. In another study, Araújo et al.

443 (2019) carry out a pan-genomics reverse vaccinology study with sixty-five complete genomes of

444 C. pseudotuberculosis. The core-proteome predicted was evaluated with Vaxign (He et al., 2010)

445 and MED 1.0 Server pipeline (Santos et al., 2013). From these analyses, the following proteins:

446 CopC, YkuE, NDH, MtrB, FtsI, and SenX3 were predicted as potential vaccine candidates by

447 both reverse vaccinology strategies.

Druggability is a concept often utilized to identify putative therapeutic targets (Owens, 2007). In this context, two studies performed a structural druggability assessment of the $C$. pseudotuberculosis proteome (Hassan et al., 2014; Radusky et al., 2015). The modelomic analyses of the predicted proteomes of fifteen strains of C. pseudotuberculosis led to the prediction of 34 potential targets, which are bacterial essentials proteins non-host homologous

453 (human, horse, cow, and sheep). These proteins are related to both physiological processes and virulence and represent a dataset composed of potential druggable targets that may be in the development of compounds against C. pseudotuberculosis infection. In another study, Barh \& cols (2011) identified 38 conserved common targets among C. pseudotuberculosis strains 
457 (1002_ovis, C231_ovis, I19_ovis, and FRC41_ovis) and CMN species (C.diphtheriae, C.

458 glutamicum, Mycobacterium tuberculosis). In this study, the authors applied the comparative and

459 subtractive genomics approaches to identify the potential targets. Among the 38 potential targets, 46020 are non-homologous to goats, sheep, bovine, horses, and humans. Further, the modeled 461 analysis and virtual screening to the targets MurA, MurE, FolP, NrdL, dcd, NrdH found five 462 specific compounds for each target, in addition, one compound [c5( Dcd)/c1( NrdL)] show 463 specificity in targeting dcd and nrdL. On the other hand, the in silico prediction of the Protein-

464 protein interaction networks of 15 C. pseudotuberculosis strains allow the identification of 41 465 essential proteins of this pathogen, non-host homologous, the authors suggest this set of proteins 466 as potential therapeutic targets (Folador et al., 2016). Among them, 24 proteins had no 467 significant hit against at least one host; the authors suggest this set of proteins as potential 468 therapeutic targets.

Finally, when summarized all proteins identified across these different approaches described in this section, the following proteins: 50S ribosomal protein L1, 50S ribosomal 471 protein L30, HlyD, HtaA domain-containing protein, NLP/P60 protein, RpfB, NrdI, SenX3, 472 SlpA, NusG, Hypothetical protein (Cp1002_0126a/ ADL20032.2) and CmtB/esterase (CP09720)

473 were identified at least two different studies (Table S.2). Until now, the following targets:

474 CP09720 (identified by SERPA and MED tool), CP01850 (identified by MED tool), and CiuA 475 (identified by $\mathrm{TnFuZ}$ system) presented the most promising results when applied as antigen in 476 either diagnostic or vaccine formulation against the C. pseudotuberculosis infection. In addition, 477 according to the results presented in these works (Rezende et al., 2016; Silva et al., 2018; Silva et 478 al., 2019; Brilhante Bezerra et al., 2020) MED, SERPA, and TnFuZ are suitable tools to identify 479 vaccine candidate and diagnostic targets. However, more detailed studies are needed to assess 
480 the experimental efficacy of all identified targets in drugs, candidate vaccines, and diagnostic

481 methods to combat the illness caused by this pathogen.

\section{Moonlight proteins in $C$. pseudotuberculosis}

483 Moonlight proteins are multifunctional proteins, which exhibit different physiological functions

484 in the same organism, depending on the cellular localization and multiple binding sites (Jeffery,

485 1999). These proteins are identified frequently in various types of organisms. Currently,

486 hundreds of moonlighting proteins are present in databases like MoonProt (Mani et al., 2015)

487 and MultitaskProtDB (Franco-Serrano et al., 2018). The world of moonlighting proteins

488 comprises different proteins such as receptors, enzymes, transcriptional factors, chaperones, and

489 scaffolds (Jeffery, 2014). In prokaryotic, moonlight proteins are present in the cell surface or

490 extracellular environment. Many of these proteins act as adhesins when exposed to cell surfaces,

491 thus contributing to bacterial colonization (Jeffery, 2018). However, the pathway used for these

492 proteins to be secreted or exposed to the cell surface is unknown. Some studies suggest that the

493 release of these proteins occurs through cell lysis, outer-membrane vesicles, increased membrane

494 permeability, or decrease membrane integrity (Ebner and Gotz, 2019). In bacterial pathogen

495 moonlight proteins play a role in the pathogenesis promoting adhesion or invasion to host cells

496 and contributing to evasion of host immune response (Henderson \& Martin, 2013; Ebner \& Gotz, 497 2019).

498

499

500

501

Moonlight proteins have been detected in both exoproteome and surfaceome of $C$.

pseudotuberculosis (Table 2). Interestingly, metabolic enzymes like enolase and GAPDH were not detected in the bacterial surfaceome grown in laboratory standard conditions, only in the shaving of RLC001_ovis collected directly from sheep lymph nodes (Rees et al., 2015a). In 
502 addition, enolase was also detected in the exoproteome of 1002 ovis upon serial passage to the

503 murine host (Silva et al., 2017a). Studies showed that both enolase and GAPDH of Streptococcus

504 pneumoniae contribute to adhesion and evasion from the host immune system (Bergmann,

505 Rohde, \& Hammerschmidt, 2004; Agarwal et al., 2012). On the other hand, in S. aureus,

506 GAPDH is related to metal uptake, invasion, and immunomodulation of the host immune system,

507 while enolase contributes to invasion and biofilm formation (Hemmadi \& Biswas, 2020).In the

508 cell surface of Mycobacterium tuberculosis, GAPDH act as a lactoferrin receptor (Malhotra et

509 al., 2017). Already enolase contributes to binds this pathogen to human plasminogen (Rahi et al.,

510 2017). In addition to its metabolic functions and contributions to bacterial pathogenicity, some

511 moonlight proteins, such as 1,6-bisphosphate aldolase (Sun et al., 2015), GAPDH (Sun et al.,

512 2017), enolase (Rahi et al., 2017) and Hsp60 (Bajzert et al., 2018) are able to induce an immune

513 response. Due to the results presented in these studies, these moonlight proteins might represent

514 potential therapeutic targets. Nevertheless, studies futures are necessary to determine the

515 extracytoplasmic function of these moonlight proteins on the pathophysiology of $C$.

516 pseudotuberculosis.

517 Hypothetical proteins

Bioinformatics tools have been helpful to obtain information about hypothetical proteins;

519 these tools can predict domain and structure proteins, which provide information about putative

520 biological function or association to the biologicals pathway. Araújo et al. (2020) used several

521 bioinformatics tools to perform the functional annotation of 80 hypothetical proteins from the

522 core genome of 32 strains of $C$. pseudotuberculosis. In addition, due to the broad pipeline

523 adopted in this study, the authors determined the physicochemical parameters and subcellular

524 localization of these 80 hypothetical proteins.

Peer] reviewing PDF | (2021:05:61050:2:0:NEW 25 Sep 2021) 
528 genome of C. pseudotuberculosis (Pinto et al., 2014; Gomide et al., 2018a; Gomide et al.,

529 2018b; Ibraim et al., 2019; Fu et al., 2020). Regarding proteomics, this discipline takes

530 advantage of transcriptomics studies over this type of study. Proteins are the final product of

531 genic expression, and proteomes represent the complete set of proteins produced by a genome.

532 Thus, a proteomic study can demonstrate the experimental evidence of hypothetical proteins,

533 which from now on can be called unknown function proteins. According to proteomic studies of

534 C. pseudotuberculosis the presence of unknown functional proteins range from 14 to $30 \%$ and

535 many of these proteins were detected under different physiological conditions. Thus more efforts

536 are necessary to characterize unknown function proteins and evaluate the role of these proteins in

537 the C. pseudotuberculosis pathophysiology. Moreover, studies show that some unknown

538 function proteins represent potential targets to be utilized in immunoassays (Rezende et al 2016;

539 Silva et al., 2019).

\section{Conclusion and Future directions}

541 This review summarized the different proteomic strategies and bioinformatics utilized to

542 promote a global functional analysis of the genome of C. pseudotuberculosis at the protein level.

543 These studies allowed the validation of genomic in silico data. In addition to the identification of

544 several proteins related to different biological processes, which contribute to the pathophysiology

545 of C. pseudotuberculosis. Moreover, the inventory of proteins detected by different

546 immunoproteomics strategies allowed the identification of promising targets to diagnostic

547 methods, drugs, or vaccine formulations against the C. pseudotuberculosis infection. Overall, 
548 these proteomics studies contributed to our understanding of different aspects of the

549 pathophysiology of C. pseudotuberculosis. Despite all this information generated, the

550 incorporation of methodologies/techniques such as metabolomics, immunology, biochemical,

551 and genetics is necessary to complement these proteomic studies.

\section{Acknowledgments}

553 The authors would like to thank the Brazilian Federal Agency for the Support and Evaluation of

554 Graduate Education (CAPES), Minas Gerais Research Foundation (FAPEMIG), Paraense

555 Amazon Foundation for Support to Studies and Research (FAPESPA), and the National Council

556 for Scientific and Technological Development (CNPq). National Council for Scientific and

557 Technical Research (CONICET).

\section{Reference}

559 Agarwal V, Hammerschmidt S, Malm S, Bergmann S, Riesbeck K, Blom AM. (2012). Enolase

560 of Streptococcus pneumoniae binds human complement inhibitor C4b-binding protein and

561 contributes to complement evasion. J Immunol. 189:3575-3584. DOI:

$56210.4049 /$ jimmunol.1102934.

563 Aljannat MAK, Oldfield NJ, Albasri HM, Dorrington LKG, Ohri RL, Wooldridge KG, Turner

564 DPJ. (2020). The moonlighting peroxiredoxin-glutaredoxin in Neisseria meningitidis binds

565 plasminogen via a C-terminal lysine residue and contributes to survival in a whole blood model.

566 Microb Pathog. 139:103890. DOI: 10.1016/j.micpath.2019.103890.

567 Almeida S, Tiwari S, Mariano D, Souza F, Jamal SB, Coimbra N, Raittz RT, Dorella FA,

568 Carvalho AF, Pereira FL, Soares Sde C, Leal CA, Barh D, Ghosh P, Figueiredo H, Moura-Costa

569 LF, Portela RW, Meyer R, Silva A, Azevedo V. (2016). The genome anatomy of

570 Corynebacterium pseudotuberculosis VD57 a highly virulent strain causing Caseous

571 lymphadenitis. Stand Genomic Sci. 11:29. DOI: 10.1186/s40793-016-0149-7.

572 Araújo CL, Alves J, Nogueira W, Pereira LC, Gomide AC, Ramos R, Azevedo V, Silva A, 573 Folador A. (2019). Prediction of new vaccine targets in the core genome of Corynebacterium 574 pseudotuberculosis through omics approaches and reverse vaccinology. Gene. 702:36-45. DOI: 575 10.1016/j.gene.2019.03.049. 
576 Araújo CL, Blanco I, Souza L, Tiwari S, Pereira LC, Ghosh P, Azevedo V, Silva A, Folador A.

577 (2020). In silico functional prediction of hypothetical proteins from the core genome of

578 Corynebacterium pseudotuberculosis biovar ovis. PeerJ. 8: e9643. DOI: 10.7717/peerj.9643.

579 Baird GJ, Fontaine MC. (2007). Corynebacterium pseudotuberculosis and its role in ovine

580 caseous lymphadenitis. J Comp Pathol. 137:179-210. DOI: 10.1016/j.jcpa.2007.07.002.

581 Bajzert J, Gorczykowski M, Galli J, Stefaniak T. (2018). The evaluation of immunogenic impact 582 of selected bacterial, recombinant Hsp60 antigens in DBA/2J mice. Microb. Pathog. 115:100-

583 111. DOI: 10.1016/j.micpath.2017.12.001.

584 Bambini S, Rappuoli R. (2009). The use of genomics in microbial vaccine development. Drug

585 Discov Today. 14:252-260. DOI: 10.1016/j.drudis.2008.12.007.

586 Barbier M, Owings JP, Martínez-Ramos I, Damron FH, Gomila R, Blázquez J, Goldberg JB, 587 Albertí S. (2013). Lysine trimethylation of EF-Tu mimics platelet-activating factor to initiate 588 Pseudomonas aeruginosa pneumonia. mBio. 4:e00207-13. DOI: 10.1128/mBio.00207-13.

589 Barh D, Jain N, Tiwari S, Parida BP, D'Afonseca V, Li L, Ali A, Santos AR, Guimarães LC, de 590 Castro Soares S, Miyoshi A, Bhattacharjee A, Misra AN, Silva A, Kumar A, Azevedo V. (2011

591 ). A novel comparative genomics analysis for common drug and vaccine targets in

592 Corynebacterium pseudotuberculosis and other CMN group of human pathogens. Chem Biol

593 Drug Des. 78:73-84. DOI: 10.1111/j.1747-0285.2011.01118.x.

594 Barinov A, Loux V, Hammani A, Nicolas P, Langella P, Ehrlich D, Maguin E, van de Guchte M. 595 (2009). Prediction of surface exposed proteins in Streptococcus pyogenes, with a potential 596 application to other Gram-positive bacteria. Proteomics. 9:61-73. DOI:

597 10.1002/pmic.200800195.

598 Barksdale L. (1970). Corynebacterium diphtheriae and its relatives. Bacteriol Rev. 34:378-422. 599 DOI: $10.1128 /$ br.34.4.378-422.1970.

600 Batey RG. Pathogenesis of caseous lymphadenitis in sheep and goats. (1986). Aust Vet J. 601 63:269-272. DOI: 10.1111/j.1751-0813.1986.tb08064.x.

602 Bendtsen JD, Nielsen H, Widdick D, Palmer T, Brunak S. (2005a). Prediction of twin-arginine 603 signal peptides. BMC Bioinformatics. 6:167. DOI: 10.1186/1471-2105-6-167.

604 Bendtsen JD, Kiemer L, Fausbøll A, Brunak S. (2005b). Non-classical protein secretion in 605 bacteria. BMC Microbiol. 2005b 5:58. DOI: 10.1186/1471-2180-5-58.

606 Bergmann S, Rohde M, Hammerschmidt S. (2004). Glyceraldehyde-3-phosphate dehydrogenase 607 of Streptococcus pneumoniae is a surface-displayed plasminogen-binding protein. Infect Immun. 608 72:2416-2419. DOI: 10.1128/iai.72.4.2416-2419.2004.

609 Biberstein EL, Knight HD, Jang S. (1971). Two biotypes of Corynebacterium 610 pseudotuberculosis. Vet Rec. 89:691-692. DOI: 10.1136/vr.89.26.691. 
611 Billington SJ, Esmay PA, Songer JG, Jost BH. Identification and role in virulence of putative 612 iron acquisition genes from Corynebacterium pseudotuberculosis. FEMS Microbiol Lett. 208:41613 45. 2002. DOI: 10.1111/j.1574-6968.2002.tb11058.x.

614 Blom AM, Bergmann S, Fulde M, Riesbeck K, Agarwal V. (2014). Streptococcus pneumoniae 615 phosphoglycerate kinase is a novel complement inhibitor affecting the membrane attack complex 616 formation. J Biol Chem. 289:32499-32511. DOI: 10.1074/jbc.M114.610212.

617 Boone TJ, Tyrrell GJ. (2012). Identification of the actin and plasminogen binding regions of 618 group B streptococcal phosphoglycerate kinase. J Biol Chem. 287:29035-29044. DOI:

619 10.1074/jbc.M112.361261.

620 Braithwaite CE, Smith EE, Songer JG, Reine AH. (1993). Characterization of detergent-soluble 621 proteins of Corynebacterium pseudotuberculosis. Vet Microbiol. 38:59-70. DOI: 10.1016/0378622 1135(93)90075-i.

623 Brilhante Bezerra FS, Silva Rezende AF, Oliveira Silva MT, Sena-Lopes Â, Roesch-Ely M, 624 Pêgas Henriques JA, Padilha FF, Carvalho Azevedo VA, Dias Portela RW, Seixas FK, Collares 625 TV, Savegnago L, Borsuk S. (2020). The combination of Brazilian red propolis and recombinant 626 protein rCP01850 in the immunoprophylaxis of Corynebacterium pseudotuberculosis infection 627 in mice. Microb Pathog. 149:104354. DOI: 10.1016/j.micpath.2020.104354.

628 Britz E, Spier SJ, Kass PH, Edman JM, Foley JE. (2014). The relationship between 629 Corynebacterium pseudotuberculosis biovar equi phenotype with location and extent of lesions 630 in horses. Vet J. 200:282-286. DOI: 10.1016/j.tvj1.2014.03.009

631 Broadbent JA, Broszczak DA, Tennakoon IUK, Huygens F. (2016). Pan-proteomics, a concept 632 for unifying quantitative proteome measurements when comparing closely related bacterial 633 strains. Expert Rev Proteomics. 13:355-365. DOI: 10.1586/14789450.2016.1155986.

634 Brum AA, Rezende AFS, Brilhante FS, Collares T, Begnine K, Seixas FK, Collares TV, 635 Dellagostin OA, Azevedo V, Santos A, Portela RW, Borsuk S. (2017). Recombinant esterase 636 from Corynebacterium pseudotuberculosis in DNA and subunit recombinant vaccines partially 637 protects mice against challenge. J Med Microbiol. 66:635-642. DOI: 10.1099/jmm.0.000477.

638 Burkovski A. (2013). Cell envelope of corynebacteria: structure and influence on pathogenicity. 639 ISRN Microbiol. 21;2013:935736. DOI: 10.1155/2013/935736.

640 Candela M, Biagi E, Centanni M, Turroni S, Vici M, Musiani F, Vitali B, Bergmann S, 641 Hammerschmidt S, Brigidi P. (2009). Bifidobacterial enolase, a cell surface receptor for human 642 plasminogen involved in the interaction with the host. Microbiology (Reading). 155:3294-3303. 643 DOI: 10.1099/mic.0.028795-0.

644 Candela M, Centanni M, Fiori J, Biagi E, Turroni S, Orrico C, Bergmann S, Hammerschmidt S, 645 Brigidi P. (2010). DnaK from Bifidobacterium animalis subsp. lactis is a surface-exposed human 
646 plasminogen receptor upregulated in response to bile salts. Microbiology. 156:1609-1618. DOI: 647 10.1099/mic.0.038307-0.

648 Carneiro CR, Postol E, Nomizo R, Reis LF, Brentani RR. (2004). Identification of enolase as a 649 laminin-binding protein on the surface of Staphylococcus aureus. Microbes Infect. 6:604-608.

650 DOI: 10.1016/j.micinf.2004.02.003.

651 Cassat JE, Skaar EP. (2013). Iron in infection and immunity. Cell Host Microbe. 13:509652 519. DOI: 10.1016/j.chom.2013.04.010.

653 Chandran R, Puthukkichal DR, Suman E, Mangalore SK. (2016). Diphtheroids-important 654 nosocomial pathogens. J Clin Diagn Res. 10:DC28-DC31. doi:10.7860/JCDR/2016/19098.9043.

655 Cordwell SJ, Nouwens AS, Walsh BJ. (2001). Comparative proteomics of bacterial pathogens.

656 Proteomics. 1:461-472. DOI: 10.1002/1615-9861(200104).

657 Costerton JW, Stewart PS, Greenberg EP. (1999). Bacterial biofilms: a common cause of 658 persistent infections. Science. 284:1318-1322. DOI: 10.1126/science.284.5418.1318.

659 Daniely D, Portnoi M, Shagan M, Porgador A, Givon-Lavi N, Ling E, Dagan R, Mizrachi 660 Nebenzahl Y. (2006). Pneumococcal 6-phosphogluconate-dehydrogenase, a putative adhesin, 661 induces protective immune response in mice. Clin Exp Immunol. 144:254-263. DOI:

$66210.1111 /$ j.1365-2249.2006.03047.x.

663 de Sá MCA, da Silva WM, Rodrigues CCS, Rezende CP, Marchioro SB, Rocha Filho JTR, 664 Sousa TdJ, de Oliveira HP, da Costa MM, Figueiredo HCP, Portela RD, Castro TLdP, Azevedo 665 V, Seyffert N and Meyer R (2021) Comparative proteomic analyses between biofilm-forming 666 and non-biofilm-forming strains of Corynebacterium pseudotuberculosis Isolated From Goats. 667 Front. Vet. Sci. 8:614011. DOI: 10.3389/fvets.2021.614011.

668 Dennison C, Lovrien R. (1997). Three-phase partitioning: concentration and purification of 669 proteins. Protein Expr Purif. 11:149-161. DOI: 10.1006/prep.1997.0779.

670 Desvaux M, Candela T, Serror P. (2018). Surfaceome and proteosurfaceome in parietal 671 monoderm bacteria: focus on protein cell-surface display. Front Microbiol. 9:100. DOI: $67210.3389 /$ fmicb.2018.00100.

673 Desvaux M, Hébraud M, Talon R, Henderson IR. (2009). Secretion and subcellular localizations 674 of bacterial proteins: a semantic awareness issue. Trends Microbiol. 17:139-145. DOI:

675 10.1016/j.tim.2009.01.004.

676 Dorella FA, Pacheco LG, Oliveira SC, Miyoshi A, Azevedo V. (2006a). Corynebacterium 677 pseudotuberculosis: microbiology, biochemical properties, pathogenesis and molecular studies of 678 virulence. Vet Res. 37:201-218. DOI: 10.1051/vetres:2005056. 
679 Dorella FA, Estevam EM, Pacheco LG, Guimarães CT, Lana UG, Gomes EA, Barsante MM, 680 Oliveira SC, Meyer R, Miyoshi A, Azevedo V. (2006b). In vivo insertional mutagenesis in 681 Corynebacterium pseudotuberculosis: an efficient means to identify DNA sequences encoding 682 exported proteins. Appl Environ Microbiol. 72:7368-7372. DOI: 10.1128/AEM.00294-06.

683 Dorella FA, Gala-Garcia A, Pinto AC, Sarrouh B, Antunes CA, Ribeiro D, Aburjaile FF, Fiaux 684 KK, Guimarães LC, Seyffert N, El-Aouar RA, Silva R, Hassan SS, Castro TL, Marques WS, 685 Ramos R, Carneiro A, de Sá P, Miyoshi A, Azevedo V, Silva A. (2013). Progression of 'omics' 686 methodologies for understanding the pathogenicity of Corynebacterium pseudotuberculosis: the 687 Brazilian experience. Comput Struct Biotechnol J. 6:e201303013. DOI: 10.5936/csbj.201303013.

688 Ebner P, Gotz F. (2019). Bacterial excretion of cytoplasmic proteins (ECP): Occurrence, 689 Mechanism, and Function. Trends Microbiol. 27:176-187. DOI: 10.1016/j.tim.2018.10.006.

690 Ellis JA, Hawk DA, Mills KW, Pratt DL. (1991). Antigen specificity and activity of ovine 691 antibodies induced by immunization with Corynebacterium pseudotuberculosis culture filtrate. 692 Vet Immunol Immunopathol. 28:303-316. DOI: 10.1016/0165-2427(91)90122-s.

693 Falisse-Poirrier N, Ruelle V, ElMoualij B, Zorzi D, Pierard O, Heinen E, De Pauw E, Zorzi W. 694 (2006). Advances in immunoproteomics for serological characterization of microbial antigens. J 695 Microbiol Methods. 67:593-596. DOI: 10.1016/j.mimet.2006.05.002.

696 Ferrari CK, Souto PC, França EL, Honorio-França AC. (2011). Oxidative and nitrosative stress 697 on phagocytes function: from effective defense to immunity evasion mechanisms. Arch Immunol 698 Ther Exp (Warsz). 59:441-448. DOI: 10.1007/s00005-011-0144-z.

699

700

701

702

703

704

705

706

707

708

709

710

711

712

713
Floden AM, Watt JA, Brissette CA. (2011). Borrelia burgdorferi enolase is a surface-exposed plasminogen binding protein. PLoS One. 6;e27502. DOI: 10.1371/journal.pone.0027502.

Folador EL, de Carvalho PV, Silva WM, Ferreira RS, Silva A, Gromiha M, Ghosh P, Barh D, Azevedo V, Röttger R. (2016). In silico identification of essential proteins in Corynebacterium pseudotuberculosis based on protein-protein interaction networks. BMC Syst Biol. 10:103. DOI: 10.1186/s12918-016-0346-4.

Franco-Serrano L, Hernández S, Calvo A, Severi MA, Ferragut G, Pérez-Pons J, Piñol J, Pich Ò, Mozo-Villarias Á, Amela I, Querol E, Cedano J. (2018). Multitaskprotdb-II: an update of a database of multitasking/moonlighting proteins. Nucleic Acids Res. 46(D1):D645-D648. DOI: 10.1093/nar/gkx1066.

Fu M, Su H, Su Z, Yin Z, Jin J, Wang L, Zhang Q, Xu X. (2020). Transcriptome analysis of Corynebacterium pseudotuberculosis-infected spleen of dairy goats. Microb Pathog.

147:104370. DOI: 10.1016/j.micpath.2020.104370.

Fulde M, Bernardo-García N, Rohde M, Nachtigall N, Frank R, Preissner KT, Klett J, Morreale A, Chhatwal GS, Hermoso JA, Bergmann S. (2014). Pneumococcal phosphoglycerate kinase

Peer] reviewing PDF | (2021:05:61050:2:0:NEW 25 Sep 2021) 
714 interacts with plasminogen and its tissue activator. Thromb Haemost. 111:401-416. DOI:

715 10.1160/TH13-05-0421.

716 Fulton KM, Baltat I, Twine SM. (2019). Immunoproteomics methods and techniques. Methods

717 Mol Biol. 2024:25-58. DOI: 10.1007/978-1-4939-9597-4_2.

718 Galán JE, Waksman G. (2018). Protein-injection machines in bacteria. Cell. 172:1306-1318.

719 DOI: $10.1016 /$ j.cell.2018.01.034.

720 Galvão CE, Fragoso SP, de Oliveira CE, Forner O, Pereira RRB, Soares CO, Rosinha GMS.

721 (2017). Identification of new Corynebacterium pseudotuberculosis antigens by

722 immunoscreening of gene expression library. BMC Microbiol. 17:202. DOI: 10.1186/s12866-

$723 \quad 017-1110-7$.

724 Garduño RA, Garduño E, Hoffman PS. (1998). Surface-associated hsp60 chaperonin of

725 Legionella pneumophila mediates invasion in a HeLa cell model. Infect Immun. 66:4602-4610.

726 DOI: 10.1128/IAI.66.10.4602-4610.1998.

727 Glenting J, Beck HC, Vrang A, Riemann H, Ravn P, Hansen AM, Antonsson M, Ahrné S,

728 Israelsen H, Madsen S. (2013). Anchorless surface associated glycolytic enzymes from

729 Lactobacillus plantarum 299v bind to epithelial cells and extracellular matrix proteins. Microbiol

730 Res. 168:245-253. DOI: 10.1016/j.micres.2013.01.003.

731 Gibson CM, Caparon MG. (2002). Alkaline phosphatase reporter transposon for identification of 732 genes encoding secreted proteins in gram-positive microorganisms. Appl Environ Microbiol.

733 68:928-32. DOI: 10.1128/AEM.68.02.928-932.2002.

734 Gomide ACP, de Sá PG, Cavalcante ALQ, de Jesus Sousa T, Gomes LGR, Ramos RTJ,

735 Azevedo V, Silva A, Folador ARC. (2018a). Heat shock stress: Profile of differential expression

736 in Corynebacterium pseudotuberculosis biovar Equi. Gene. 645:124-130. DOI:

737 10.1016/j.gene.2017.12.015.

738 Gomide ACP, Ibraim IC, Alves JTC, de Sá PG, de Oliveira Silva YR, Santana MP, Silva WM, 739 Folador EL, Mariano DCB, de Paula Castro TL, Barbosa S, Dorella FA, Carvalho AF, Pereira 740 FL, Leal CAG, Figueiredo HCP, Azevedo V, Silva A, Folador ARC. (2018b). Transcriptome 741 analysis of Corynebacterium pseudotuberculosis biovar Equi in two conditions of the 742 environmental stress. Gene. 677:349-360. DOI: 10.1016/j.gene.2018.08.028.

743 Gründel A, Pfeiffer M, Jacobs E, Dumke R. (2015). Network of surface-displayed glycolytic 744 enzymes in Mycoplasma pneumoniae and Their Interactions with Human Plasminogen. Infect 745 Immun. 84:666-676. DOI: 10.1128/IAI.01071-15.

746 Haas DJ, Dorneles EM, Spier SJ, Carroll SP, Edman J, Azevedo VA, Heinemann MB, Lage AP. 747 (2017). Molecular epidemiology of Corynebacterium pseudotuberculosis isolated from horses in 748 California. Infect Genet Evol. 49:186-194. DOI: 10.1016/j.meegid.2016.12.011. 
749 Hammerschmidt S, Rohde M, Preissner KT. (2019). Extracellular matrix interactions with Gram750 positive pathogens. Microbiol Spectr. 7(2). DOI: 10.1128/microbiolspec.GPP3-0041-2018.

751 Hassan SS, Tiwari S, Guimarães LC, Jamal SB, Folador E, Sharma NB, de Castro Soares S, 752 Almeida S, Ali A, Islam A, Póvoa FD, de Abreu VA, Jain N, Bhattacharya A, Juneja L, Miyoshi

753 A, Silva A, Barh D, Turjanski A, Azevedo V, Ferreira RS. (2014). Proteome scale comparative

754 modeling for conserved drug and vaccine targets identification in Corynebacterium

755 pseudotuberculosis. BMC Genomics. 15:S3 DOI: 10.1186/1471-2164-15-S7-S3.

756 He P, Moran GR. (2011). Structural and mechanistic comparisons of the metal-binding members

757 of the vicinal oxygen chelate (VOC) superfamily. J Inorg Biochem. 105:1259-1272. DOI:

758 10.1016/j.jinorgbio.2011.06.006.

759

760

761

762

763

764

765

766

767

768

769

770

771

772

773

774

775

776

777

778

779

780

781

782

783

He Y, Xiang Z, Mobley HL. (2010). Vaxign: the first web-based vaccine design program for reverse vaccinology and applications for vaccine development. J Biomed Biotechnol. 2010, 297505. DOI: $10.1155 / 2010 / 297505$.

Hemmadi V, Biswas M. (2020). An overview of moonlighting proteins in Staphylococcus aureus infection. Arch Microbiol. 13:1-18. DOI: 10.1007/s00203-020-02071-y.

Henderson B, Martin A. (2013). Bacterial moonlighting proteins and bacterial virulence. Curr Top Microbiol Immunol. 358:155-213. DOI: 10.1007/82_2011_188.

Hennequin C, Porcheray F, Waligora-Dupriet A, Collignon A, Barc M, Bourlioux P, Karjalainen T. (2001). Groel (Hsp60) of Clostridium difficile is involved in cell adherence. Microbiology. 147:87-96. DOI: 10.1099/00221287-147-1-87.

Hickey TB, Ziltener HJ, Speert DP, Stokes RW. (2010). Mycobacterium tuberculosis employs Cpn60.2 as an adhesin that binds CD43 on the macrophage surface. Cell Microbiol. 12:16341647. DOI: $10.1111 /$ j.1462-5822.2010.01496.x.

Ibraim IC, Parise MTD, Parise D, Sfeir MZT, de Paula Castro TL, Wattam AR, Ghosh P, Barh D, Souza EM, Góes-Neto A, Gomide ACP, Azevedo V. (2019). Transcriptome profile of Corynebacterium pseudotuberculosis in response to iron limitation. BMC Genomics. 20:663. DOI: $10.1186 / \mathrm{s} 12864-019-6018-1$.

Ikeda R, Furuya H. (2011). Interaction of triosephosphate isomerase from Staphylococcus aureus with plasminogen. Microbiol Immunol. 55:855-862. DOI: 10.1111/j.1348-0421.2011.00392.x.

Jeffery CJ. (1999). Moonlighting proteins. Trends Biochem Sci. 24:8-11. DOI: 10.1016/s09680004(98)01335-8.

Jeffery CJ. (2014). An introduction to protein moonlighting. Biochem Soc Trans. 42:1679-83. DOI: $10.1042 / B S T 20140226$.

Jeffery CJ. (2018). Intracellular proteins moonlighting as bacterial adhesion factors. AIMS Microbiol. 4:362-376. DOI: 10.3934/microbiol.2018.2.362. 
784 Kazmierczak MJ, Wiedmann M, Boor KJ. (2005). Alternative sigma factors and their roles in 785 bacterial virulence. Microbiol Mol Biol Rev. 69:527-43. DOI: 10.1128/MMBR.69.4.527-

786543.2005.

787 Kesimer M, Kiliç N, Mehrotra R, Thornton DJ, Sheehan JK. (2009). Identification of salivary 788 mucin MUC7 binding proteins from Streptococcus gordonii. BMC Microbiol. 9:163. DOI:

789 10.1186/1471-2180-9-163.

790 Kinoshita H, Ohuchi S, Arakawa K, Watanabe M, Kitazawa H, Saito T. (2016). Isolation of 791 lactic acid bacteria bound to the porcine intestinal mucosa and an analysis of their moonlighting 792 adhesins. Biosci Microbiota Food Health.35:185-196. DOI: 10.12938/bmfh.16-012.

793 Klade CS. (2002). Proteomics approaches towards antigen discovery and vaccine development. 794 Curr Opin Mol Ther. 4:216-223.

795 Kline KA, Fälker S, Dahlberg S, Normark S, Henriques-Normark B. (2009). Bacterial adhesins 796 in host-microbe interactions. Cell Host Microbe. 5:580-592. DOI: 10.1016/j.chom.2009.05.011.

797 Knaust A, Weber MV, Hammerschmidt S, Bergmann S, Frosch M, Kurzai O. (2007). Cytosolic 798 proteins contribute to surface plasminogen recruitment of Neisseria meningitidis. J Bacteriol. 799 189:3246-3255. DOI: 10.1128/JB.01966-06.

800 Kumar J, Singh F, Tripathi BN, Kumar R, Dixit SK, Sonawane GG. (2012). Epidemiological, 801 bacteriological, and molecular studies on caseous lymphadenitis in Sirohi goats of Rajasthan, 802 India. Trop Anim Health Prod. 44:1319-1322. DOI: 10.1007/s11250-012-0102-8.

803 Maffei B, Francetic O, Subtil A. (2017). Tracking proteins secreted by bacteria: what's in the 804 toolbox? Front Cell Infect Microbiol. 7:221. DOI: 10.3389/fcimb.2017.00221.

805 Malhotra H, Patidar A, Boradia VM, Kumar R, Nimbalkar RD, Kumar A, Gani Z, Kaur R, Garg 806 P, Raje M, Raje CI. (2017). Mycobacterium tuberculosis glyceraldehyde-3-phosphate 807 dehydrogenase (GAPDH) functions as a receptor for human lactoferrin. Front. Cell Infect. 808 Microbiol. 7, 245. DOI: 10.3389/fcimb.2017.00245.

809 Mani M, Chen C, Amblee V, Liu H, Mathur T, Zwicke G, Zabad S, Patel B, Thakkar J, Jeffery 810 CJ. (2015). Moonprot: a database for proteins that are known to moonlight. Nucleic Acids Res. 811 43:D277-82. DOI: 10.1093/nar/gku954.

812 Matta SK, Agarwal S, Bhatnagar R. (2010). Surface localized and extracellular Glyceraldehyde813 3-phosphate dehydrogenase of Bacillus anthracis is a plasminogen binding protein. Biochim 814 Biophys Acta. 1804:2111-2120. DOI: 10.1016/j.bbapap.2010.08.004.

815 McKean SC, Davies JK, Moore RJ. (2007). Expression of phospholipase D, the major virulence 816 factor of Corynebacterium pseudotuberculosis, is regulated by multiple environmental factors 817 and plays a role in macrophage death. Microbiology. 153:2203-2211. DOI:

818 10.1099/mic.0.2007/005926-0. 
819 McNamara PJ, Bradley GA, Songer JG. (1994). Targeted mutagenesis of the phospholipase D 820 gene results in decreased virulence of Corynebacterium pseudotuberculosis. Mol Microbiol.

821 12:921-230. DOI: 10.1111/j.1365-2958.1994.tb01080.x.

822 Meyer R, Carminati R, Bahia R, Vale V, Viegas S, Martinez T, Nascimento I, Schaer R, Silva J, 823 Ribeiro M, Regis L, Paule B, Freire S. (2002). Evaluation of the goats humoral immune response 824 induced by the Corynebacterium pseudotuberculosis lyophilized live vaccine. J Med Biol Sci.

825 1:42-48. DOI: 10.9771/cmbio.v1i1.4093.

826

827

828

829

Mölkänen T, Tyynelä J, Helin J, Kalkkinen N, Kuusela P. (2002). Enhanced activation of bound plasminogen on Staphylococcus aureus by staphylokinase. FEBS Lett. 517:72-78. DOI: 10.1016/s0014-5793(02)02580-2.

Moraes PM, Seyffert N, Silva WM, Castro TL, Silva RF, Lima DD, Hirata R Jr, Silva A, Miyoshi A, Azevedo V. (2014). Characterization of the Opp peptide transporter of Corynebacterium pseudotuberculosis and its role in virulence and pathogenicity. Biomed Res Int. 2014:489782. DOI: 10.1155/2014/489782.

Moura-Costa LF, Bahia RC, Carminati R, Vale VL, Paule BJ, Portela RW, Freire SM, Nascimento I, Schaer R, Barreto LM, Meyer R. (2008). Evaluation of the humoral and cellular immune response to different antigens of Corynebacterium pseudotuberculosis in Canindé goats and their potential protection against caseous lymphadenitis. Vet Immunol Immunopathol. 126:131-141. DOI: 10.1016/j.vetimm.2008.06.013.

Moura-Costa LF, Paule BJA, Azevedo V, Freire SM, Nascimento I, Schaer R, Regis LF, Vale VLC, Matos DP, Bahia RC, Carminati R, Meyer R. (2002). Chemically defined synthetic medium for Corynebacterium pseudotuberculosis culture. Rev. Bras. Saúde e Produção Animal. $3: 1-9$.

Muckle CA, Gyles CL. (1983). Relation of lipid content and exotoxin production to virulence of Corynebacterium pseudotuberculosis in mice. Am J Vet Res. 44:1149-1153.

Muckle CA, Menzies PI, Li Y, Hwang YT, van Wesenbeeck M. (1992). Analysis of the immunodominant antigens of Corynebacterium pseudotuberculosis. Vet Microbiol. 30:47-58. DOI: 10.1016/0378-1135(92)90093-9.

Nabih AM, Hussein HA, El-Wakeel SA, Abd El-Razik KA, Gomaa AM. (2018). Corynebacterium pseudotuberculosis mastitis in Egyptian dairy goats. Vet World. 11:1574-1580. DOI: 10.14202/vetworld.2018.1574-1580.

Nishiyama K, Takaki T, Sugiyama M, Fukuda I, Aiso M, Mukai T, Odamaki T, Xiao JZ, Osawa R, Okada N. (2020). Extracellular vesicles produced by Bifidobacterium longum export mucinbinding poteins. Appl Environ Microbiol. 86:e1464-20. DOI: 10.1128/AEM.01464-20.

Olaya-Abril A, Jiménez-Munguía I, Gómez-Gascón L, Rodríguez-Ortega MJ. (2014). Surfomics: shaving live organisms for a fast proteomic identification of surface proteins. J Proteomics. 97:164-176. DOI: 10.1016/j.jprot.2013.03.035. 
856 Oli AN, Obialor WO, Ifeanyichukwu MO, Odimegwu DC, Okoyeh JN, Emechebe GO, Adejumo 857 SA, Ibeanu GC. (2020). Immunoinformatics and vaccine development: an overview.

858 Immunotargets Ther. 9:13-30. DOI: 10.2147/ITT.S241064.

859 Otto A, Bernhardt J, Hecker M, Becher D. (2012). Global relative and absolute quantitation in 860 microbial proteomics. Curr Opin Microbiol. 15:364-372. DOI: 10.1016/j.mib.2012.02.005.

861 Owens J. (2007). Determining druggability. Nat Rev Drug Discov 6, 187. DOI:

$86210.1038 / \mathrm{nrd} 2275$.

863 Pacheco LG, Castro TL, Carvalho RD, Moraes PM, Dorella FA, Carvalho NB, Slade SE, 864 Scrivens JH, Feelisch M, Meyer R, Miyoshi A, Oliveira SC, Dowson CG, Azevedo V. (2012). A 865 role for sigma factor $\sigma(\mathrm{E})$ in Corynebacterium pseudotuberculosis resistance to nitric 866 oxide/peroxide stress. Front Microbiol. 3:126. DOI: 10.3389/fmicb.2012.00126.

867 Pacheco LG, Slade SE, Seyffert N, Santos AR, Castro TL, Silva WM, Santos AV, Santos SG, 868 Farias LM, Carvalho MA, Pimenta AM, Meyer R, Silva A, Scrivens JH, Oliveira SC, Miyoshi 869 A, Dowson CG, Azevedo V. (2011). A combined approach for comparative exoproteome 870 analysis of Corynebacterium pseudotuberculosis. BMC Microbiol. 11:12. DOI: 10.1186/1471871 2180-11-12.

872 Pancholi V, Fischetti VA. (1992). A major surface protein on group A streptococci is a 873 glyceraldehyde-3-phosphate-dehydrogenase with multiple binding activity. $J$ Exp Med. 176:415874 426. DOI: $10.1084 /$ jem.176.2.415.

875 Pancholi V, Fischetti VA. (1998). Alpha-enolase, a novel strong plasminogen binding protein on 876 the surface of pathogenic streptococci. J Biol Chem. 273:14503-14515. DOI:

$87710.1074 / \mathrm{jbc} .273 .23 .14503$.

878
Park SJ, Son WS, Lee BJ. (2012). Structural analysis of hypothetical proteins from Helicobacter pylori: An Approach to estimate functions of unknown or hypothetical proteins. Int. J. Mol. Sci. 13:7109-7137. DOI: 10.3390/ijms13067109.

Paule BJ, Azevedo V, Regis LF, Carminati R, Bahia CR, Vale VL, Moura-Costa LF, Freire SM, Nascimento I, Schaer R, Goes AM, Meyer R. (2003). Experimental Corynebacterium pseudotuberculosis primary infection in goats: kinetics of IgG and interferon-gamma production, IgG avidity and antigen recognition by Western blotting. Vet Immunol Immunopathol. 96:129139. DOI: $10.1016 / \mathrm{s} 0165-2427(03) 00146-6$.

Paule B, Azevedo V, Costa LFM, Freire SM, Regis LF, Vale V, Bahia R, Carminati R, Nascimento, ILO, Meyer R. (2004a). sds-page and Western blot analysis of somatic and extracellular antigens of Corynebacterium pseudotuberculosis. Revista de Ciências Médicas e Biológicas. 3:44-52.

Paule BJ, Meyer R, Moura-Costa LF, Bahia RC, Carminati R, Regis LF, Vale VL, Freire SM, Nascimento I, Schaer R, Azevedo V. (2004b). Three-phase partitioning as an efficient method

Peer] reviewing PDF | (2021:05:61050:2:0:NEW 25 Sep 2021) 
892 for extraction/concentration of immunoreactive excreted-secreted proteins of Corynebacterium

893 pseudotuberculosis. Protein Expr Purif. 34:311-316. DOI: 10.1016/j.pep.2003.12.003.

894 Pépin M, Pittet JC, Olivier M, Gohin I. (1994). Cellular composition of Corynebacterium 895 pseudotuberculosis pyogranulomas in sheep. J Leukoc Biol. 56:666-670. DOI:

$89610.1002 / \mathrm{jlb} .56 .5 .666$.

897 Pérez Montoro B, Benomar N, Caballero Gómez N, Ennahar S, Horvatovich P, Knapp CW, 898 Alonso E, Gálvez A, Abriouel H. (2018). Proteomic analysis of Lactobacillus pentosus for the 899 identification of potential markers of adhesion and other probiotic features. Food Res Int. 900 111:58-66. DOI: 10.1016/j.foodres.2018.04.072.

901 Pinto AC, de Sá PH, Ramos RT, Barbosa S, Barbosa HP, Ribeiro AC, Silva WM, Rocha FS, 902 Santana MP, de Paula Castro TL, Miyoshi A, Schneider MP, Silva A, Azevedo V. (2014). 903 Differential transcriptional profile of Corynebacterium pseudotuberculosis in response to abiotic 904 stresses. BMC Genomics. 15:14. DOI: 10.1186/1471-2164-15-14.

905 Radusky LG, Hassan S, Lanzarotti E, Tiwari S, Jamal S, Ali J, Ali A, Ferreira R, Barh D, Silva 906 A, Turjanski AG, Azevedo VA. (2015). An integrated structural proteomics approach along the 907 druggable genome of Corynebacterium pseudotuberculosis species for putative druggable 908 targets. BMC Genomics. 16:S9. DOI: 10.1186/1471-2164-16-S5-S9.

909 Rahi A, Matta SK, Dhiman A, Garhyan J, Gopalani M, Chandra S, Bhatnagar R. (2017). Enolase 910 of Mycobacterium tuberculosis is a surface-exposed plasminogen binding protein. Biochim.

911 Biophys. Acta 1861:3355-3364. DOI: 10.1016/j.bbagen.2016.08.018.

912 Rajagopal M, Walker S. (2017). Envelope structures of gram-positive bacteria. Curr Top 913 Microbiol Immunol. 404:1-44. DOI: 10.1007/82_2015_5021.

914 Rani A, Babu S. Environmental proteomic studies: closer step to understand bacterial biofilms.

915 (2018). World J Microbiol Biotechnol. 34:120. DOI: 10.1007/s11274-018-2504-x.

916 Raoufi E, Hemmati M, Eftekhari S, Khaksaran K, Mahmodi Z, Farajollahi MM, Mohsenzadegan 917 M. (2020). Epitope prediction by novel immunoinformatics approach: a state-of-the-art review.

918 Int J Pept Res Ther. 26:1155-1163. DOI: 10.1007/s10989-019-09918-z.

919 Rappuoli R. (2000). Reverse vaccinology. Curr Opin Microbiol. 3:445-450. DOI:

920 10.1016/s1369-5274(00)00119-3.

921 Raynal JT, Bastos BL, Vilas-Boas PCB, Sousa TJ, Costa-Silva M, de Sá MDCA, Portela RW, 922 Moura-Costa LF, Azevedo V, Meyer R. (2018). Identification of membrane-associated proteins 923 with pathogenic potential expressed by Corynebacterium pseudotuberculosis grown in animal 924 serum. BMC Res Notes. 11:73. DOI: 10.1186/s13104-018-3180-5.

925 Rebouças MF, Portela RW, Lima DD, Loureiro D, Bastos BL, Moura-Costa LF, Vale VL, 926 Miyoshi A, Azevedo V, Meyer R. (2011). Corynebacterium pseudotuberculosis secreted 927 antigen-induced specific gamma-interferon production by peripheral blood leukocytes: potential 
928 diagnostic marker for caseous lymphadenitis in sheep and goats. J Vet Diagn Invest. 23:213-20. 929 DOI: $10.1177 / 104063871102300204$.

930 Reddy VM, Suleman FG. (2004). Mycobacterium avium-superoxide dismutase binds to 931 epithelial cell aldolase, glyceraldehyde-3-phosphate dehydrogenase and cyclophilin A. Microb 932 Pathog. 36:67-74. DOI: 10.1016/j.micpath.2003.09.005.

933 Rees MA, Kleifeld O, Crellin PK, Ho B, Stinear TP, Smith AI, Coppel RL. (2015a). Proteomic 934 characterization of a natural host-pathogen interaction: repertoire of in vivo expressed bacterial 935 and host surface-associated proteins. J Proteome Res. 14:120-32. DOI: 10.1021/pr5010086.

936 Rees MA, Stinear TP, Goode RJ, Coppel RL, Smith AI, Kleifeld O. (2015b). Changes in protein 937 abundance are observed in bacterial isolates from a natural host. Front Cell Infect Microbiol. 938 5:71. DOI: 10.3389/fcimb.2015.00071.

939 Restrepo-Montoya D, Pino C, Nino LF, Patarroyo ME, Patarroyo MA. (2011). NclassG+: A 940 classifier for non-classically secreted Gram-positive bacterial proteins. BMC Bioinformatics. 941 12:21. DOI: 10.1186/1471-2105-12-21.

942 Rezende AFS, Brum AA, Reis CG, Angelo HR, Leal KS, Silva MTO, Simionatto S, Azevedo V, 943 Santos A, Portela RW, Dellagostin O, Borsuk S. (2016). In silico identification of 944 Corynebacterium pseudotuberculosis antigenic targets and application in immunodiagnosis. $J$ 945 Med Microbiol. 65:521-529. DOI: 10.1099/jmm.0.000263.

946 Ribeiro D, Rocha Fde S, Leite KM, Soares Sde C, Silva A, Portela RW, Meyer R, Miyoshi A, 947 Oliveira SC, Azevedo V, Dorella FA. (2014). An iron-acquisition-deficient mutant of 948 Corynebacterium pseudotuberculosis efficiently protects mice against challenge. Vet Res. 45:28. 949 DOI: 10.1186/1297-9716-45-28.

950 Ribeiro OC, Silva JAH, Oliveira SC, Meyer R, Fernandes GB. Preliminary results on a living 951 vaccince against caseous lymphadenitis. Pesquisa Agropecuaria Brasileira. 1991;26:461-465.

952 Rodríguez-Ortega MJ, Norais N, Bensi G, Liberatori S, Capo S, Mora M, Scarselli M, Doro F, 953 Ferrari G, Garaguso I, Maggi T, Neumann A, Covre A, Telford JL, Grandi G. (2006).

954 Characterization and identification of vaccine candidate proteins through analysis of the group A 955 Streptococcus surface proteome. Nat Biotechnol. 24:191-197. DOI: 10.1038/nbt1179.

956 Ruiz JC, D'Afonseca V, Silva A, Ali A, Pinto AC, Santos AR, Rocha AA, Lopes DO, Dorella 957 FA, Pacheco LG, Costa MP, Turk MZ, Seyffert N, Moraes PM, Soares SC, Almeida SS, Castro 958 TL, Abreu VA, Trost E, Baumbach J, Tauch A, Schneider MP, McCulloch J, Cerdeira LT, 959 Ramos RT, Zerlotini A, Dominitini A, Resende DM, Coser EM, Oliveira LM, Pedrosa AL, 960 Vieira CU, Guimarães CT, Bartholomeu DC, Oliveira DM, Santos FR, Rabelo ÉM, Lobo FP, 961 Franco GR, Costa AF, Castro IM, Dias SR, Ferro JA, Ortega JM, Paiva LV, Goulart LR, 962 Almeida JF, Ferro MI, Carneiro NP, Falcão PR, Grynberg P, Teixeira SM, Brommonschenkel S, 963 Oliveira SC, Meyer R, Moore RJ, Miyoshi A, Oliveira GC, Azevedo V. (2011). Evidence for 964 reductive genome evolution and lateral acquisition of virulence functions in two 
965 Corynebacterium pseudotuberculosis strains. PLoS One. 6:e18551. DOI:

966 10.1371/journal.pone.0018551.

967 Sá M, da CA, Veschi JLA, Santos GB, Amanso ES, Oliveira SAS, Mota RA, Veneroni-Gouveia 968 G, Costa MM. (2013). Activity of disinfectants and biofilm production of Corynebacterium 969 pseudotuberculosis. Pesqui Vet Bras. 33:1319-1324. DOI:10.1590/S0100-736X2013001100006.

970 Santos AR, Carneiro A, Gala-García A, Pinto A, Barh D, Barbosa E, Aburjaile F, Dorella F, 971 Rocha F, Guimarães L, Zurita-Turk M, Ramos R, Almeida S, Soares S, Pereira U, Abreu VC, 972 Silva A, Miyoshi A, Azevedo V. (2012). The Corynebacterium pseudotuberculosis in silico 973 predicted pan-exoproteome. BMC Genomics. 13:S6. DOI: 10.1186/1471-2164-13-S5-S6.

974 Santos AR, Pereira VB, Barbosa E, Baumbach J, Pauling J, Röttger R, Turk MZ, Silva A, 975 Miyoshi A, Azevedo V. (2013). Mature Epitope Density--a strategy for target selection based on 976 immunoinformatics and exported prokaryotic proteins. BMC Genomics. 14:S4. DOI:

977 10.1186/1471-2164-14-S6-S4.

978 Schaible UE, Kaufmann SH. (2004). Iron and microbial infection. Nat Rev Microbiol. 2:946-953. 979 DOI: $10.1038 /$ nrmicro1046.

980 Schmidt F, Völker U. Proteome analysis of host-pathogen interactions: Investigation of pathogen 981 responses to the host cell environment. Proteomics. 2011 11:3203-3211. DOI:

982 10.1002/pmic.201100158.

983 Selim SA. (2001). Oedematous skin disease of buffalo in Egypt. J Vet Med B Infect Dis Vet 984 Public Health. 48:241-258. DOI: 10.1046/j.1439-0450.2001.00451.x.

985 Seyffert N, Pacheco LGC, Silva WM, Castro TLP, Santos AV, Santos A, McCulloch JA, 986 Rodrigues MR, Santos SG, Farias LM, Carvalho MAR, Pimenta AMC, Silva A, Meyer R, 987 Miyoshi A, Azevedo V. 2011. Preliminary serological secretome analysis of Corynebacterium 988 pseudotuberculosis. J. Integr. Omics 1:193-197. DOI: 10.5584/jiomics.v1i2.54.

989 Seyffert N, Silva RF, Jardin J, Silva WM, Castro TL, Tartaglia NR, Santana KT, Portela RW, 990 Silva A, Miyoshi A, Le Loir Y, Azevedo V. (2014). Serological proteome analysis of 991 Corynebacterium pseudotuberculosis isolated from different hosts reveals novel candidates for 992 prophylactics to control caseous lymphadenitis. Vet Microbiol. 174:255-260. DOI: 993 10.1016/j.vetmic.2014.08.024.

994 Sha J, Erova TE, Alyea RA, Wang S, Olano JP, Pancholi V, Chopra AK. (2009). Surface995 expressed enolase contributes to the pathogenesis of clinical isolate SSU of Aeromonas 996 hydrophila. J Bacteriol. 191:3095-3107. DOI: 10.1128/JB.00005-09.

997 Sheldon JR, Laakso HA, Heinrichs DE. (2016). Iron acquisition strategies of bacterial pathogens. 998 Microbiol Spectr. 4(2). DOI: 10.1128/microbiolspec.VMBF-0010-20. 
999 Shpigel NY, Elad D, Yeruham I, Winkler M, Saran A. (1993). An outbreak of Corynebacterium 1000 pseudotuberculosis infection in an Israeli dairy herd. Vet Rec. 24:89-94. DOI:

1001 10.1136/vr.133.4.89.

1002

1003

1004

1005

1006

1007

1008

1009

1010

1011

1012

1013

1014

1015

1016

1017

1018

1019

1020

1021

1022

1023

1024

1025

1026

1027

1028

1029

1030

1031

1032

1033

1034

1035

1036

Silva JC, Gorenstein MV, Li GZ, Vissers JP, Geromanos SJ. (2006). Absolute quantification of proteins by LC-MSE: a virtue of parallel MS acquisition. Mol Cell Proteomics. 5:144-156. DOI: 10.1074/mcp.M500230-MCP200.

Silva MTO, Bezerra FSB, de Pinho RB, Begnini KR, Seixas FK, Collares T, Portela RD, Azevedo V, Dellagostin O, Borsuk S. (2018). Association of Corynebacterium

pseudotuberculosis recombinant proteins rCP09720 or rCP01850 with rPLD as immunogens in caseous lymphadenitis immunoprophylaxis. Vaccine. 36:74-83. DOI:

10.1016/j.vaccine.2017.11.029.

Silva MTO, Bezerra FSB, de Pinho RB, de Santana Ferreira C, Vivas WL, Portela RWD, Azevedo VAC, Borsuk S. (2019). The combination of Corynebacterium pseudotuberculosis recombinant proteins $\mathrm{rPLD}, \mathrm{rCP} 01850$ and $\mathrm{rCP} 09720$ for improved detection of caseous lymphadenitis in sheep by ELISA. J Med Microbiol. 68:1759-1765. DOI: 10.1099/jmm.0.001096.

Silva WM, Carvalho RD, Soares SC, Bastos IF, Folador EL, Souza GH, Le Loir Y, Miyoshi A, Silva A, Azevedo V. (2014). Label-free proteomic analysis to confirm the predicted proteome of Corynebacterium pseudotuberculosis under nitrosative stress mediated by nitric oxide. BMC Genomics. 15:1065. DOI: 10.1186/1471-2164-15-1065.

Silva WM, Carvalho RDO, Dorella FA, Folador EL, Souza GHMF, Pimenta AMC, Figueiredo HCP, Le Loir Y, Silva A, Azevedo V. (2017b). Quantitative proteomic analysis reveals changes in the benchmark Corynebacterium pseudotuberculosis biovar equi Exoproteome after Passage in a Murine Host. Front Cell Infect Microbiol. 7:325. DOI: 10.3389/fcimb.2017.00325.

Silva WM, Dorella FA, Soares SC, Souza GH, Castro TL, Seyffert N, Figueiredo H, Miyoshi A, Le Loir Y, Silva A, Azevedo V. (2017a). A shift in the virulence potential of Corynebacterium pseudotuberculosis biovar ovis after passage in a murine host demonstrated through comparative proteomics. BMC Microbiol. 17:55. DOI: 10.1186/s12866-017-0925-6.

Silva WM, Folador EL, Soares SC, Souza GHMF, Santos AV, Sousa CS, Figueiredo H, Miyoshi A, Le Loir Y, Silva A, Azevedo V. (2017c). Label-free quantitative proteomics of Corynebacterium pseudotuberculosis isolates reveals differences between Biovars ovis and equi strains. BMC Genomics. 18:451. DOI: 10.1186/s12864-017-3835-y.

Silva WM, Seyffert N, Ciprandi A, Santos AV, Castro TL, Pacheco LG, Barh D, Le Loir Y, Pimenta AM, Miyoshi A, Silva A, Azevedo V. (2013b). Differential exoproteome analysis of two Corynebacterium pseudotuberculosis biovar ovis strains isolated from goat (1002) and sheep (C231). Curr Microbiol. 67:460-465. DOI: 10.1007/s00284-013-0388-4.

Silva WM, Seyffert N, Santos AV, Castro TL, Pacheco LG, Santos AR, Ciprandi A, Dorella FA, Andrade HM, Barh D, Pimenta AM, Silva A, Miyoshi A, Azevedo V. (2013a). Identification of 
103711 new exoproteins in Corynebacterium pseudotuberculosis by comparative analysis of the

1038

1039

1040

1041

1042

1043

1044

1045

1046

1047

1048

1049

1050

1051

1052

1053

1054

1055

1056

1057

1058

1059

1060

1061

1062

1063

1064

1065

1066

1067

1068

1069

1070

1071

1072 exoproteome. Microb Pathog. 61-62:37-42. DOI: 10.1016/j.micpath.2013.05.004.

Simmons CP, Dunstan SJ, Tachedjian M, Krywult J, Hodgson AL, Strugnell RA. (1998). Vaccine potential of attenuated mutants of Corynebacterium pseudotuberculosis in sheep. Infect Immun. 66:474-479. DOI: 10.1128/IAI.66.2.474-479.1998.

Soares SC, Silva A, Trost E, Blom J, Ramos R, Carneiro A, Ali A, Santos AR, Pinto AC, Diniz C, Barbosa EG, Dorella FA, Aburjaile F, Rocha FS, Nascimento KK, Guimarães LC, Almeida S, Hassan SS, Bakhtiar SM, Pereira UP, Abreu VA, Schneider MP, Miyoshi A, Tauch A, Azevedo V. (2013a). The pan-genome of the animal pathogen Corynebacterium pseudotuberculosis reveals differences in genome plasticity between the biovar ovis and equi strains. PLoS One. 8:e53818. DOI: 10.1371/journal.pone.0053818.

Soares SC, Trost E, Ramos RT, Carneiro AR, Santos AR, Pinto AC, Barbosa E, Aburjaile F, Ali A, Diniz CA, Hassan SS, Fiaux K, Guimarães LC, Bakhtiar SM, Pereira U, Almeida SS, Abreu VA, Rocha FS, Dorella FA, Miyoshi A, Silva A, Azevedo V, Tauch A. (2013b). Genome sequence of Corynebacterium pseudotuberculosis biovar equi strain 258 and prediction of antigenic targets to improve biotechnological vaccine production. J Biotechnol. 167:135-141. DOI: 10.1016/j.jbiotec.2012.11.003.

Souza BM, Castro TL, Carvalho RD, Seyffert N, Silva A, Miyoshi A, Azevedo V. (2014). o(ecf) factors of gram-positive bacteria: a focus on Bacillus subtilis and the CMNR group. Virulence. 5:587-560. DOI: 10.4161/viru.29514.

Stefańska I, Gieryńska M, Rzewuska M, Binek M. (2010). Survival of Corynebacterium pseudotuberculosis within macrophages and induction of phagocytes death. Pol J Vet Sci. 13:143-149.

Sun X, Wang J, Zhou J, Wang H, Wang X, Wu J, He Y, Yin Y, Zhang X, Xu W. (2017). Subcutaneous immunization with Streptococcus pneumoniae GAPDH confers effective protection in mice via TLR2 and TLR4. Mol Immunol. 83:1-12. DOI: 10.1016/j.molimm.2017.01.002.

Sun Z, Shen B, Wu H, Zhou X, Wang Q, Xiao J, Zhang Y. (2015). The secreted fructose 1,6bisphosphate aldolase as a broad spectrum vaccine candidate against pathogenic bacteria in aquaculture. Fish Shellfish Immunol. 46:638-647. DOI: 10.1016/j.fsi.2015.08.001.

Tiwari S, da Costa MP, Almeida S, Hassan SS, Jamal SB, Oliveira A, Folador EL, Rocha F, de Abreu VA, Dorella F, Hirata R, de Oliveira DM, da Silva Teixeira MF, Silva A, Barh D, Azevedo V. (2014). C. pseudotuberculosis Phop confers virulence and may be targeted by natural compounds. Integr Biol (Camb). 6:1088-99. DOI: 10.1039/c4ib00140k.

Thornalley PJ. (2003). Glyoxalase I--structure, function and a critical role in the enzymatic defence against glycation. Biochem Soc Trans. 31:1343-1348. DOI: 10.1042/bst0311343. 
1073 Trost E, Ott L, Schneider J, Schröder J, Jaenicke S, Goesmann A, Husemann P, Stoye J, Dorella 1074 FA, Rocha FS, Soares Sde C, D'Afonseca V, Miyoshi A, Ruiz J, Silva A, Azevedo V, Burkovski 1075 A, Guiso N, Join-Lambert OF, Kayal S, Tauch A. (2010). The complete genome sequence of 1076 Corynebacterium pseudotuberculosis FRC41 isolated from a 12-year-old girl with necrotizing 1077 lymphadenitis reveals insights into gene-regulatory networks contributing to virulence. $B M C$ 1078 Genomics. 30;11:728. DOI: 10.1186/1471-2164-11-728.

1079 Ventura M, Canchaya C, Tauch A, Chandra G, Fitzgerald GF, Chater KF, van Sinderen D. 1080 (2007). Genomics of Actinobacteria: tracing the evolutionary history of an ancient phylum. 1081 Microbiol Mol Biol Rev. 71:495-548. DOI: 10.1128/MMBR.00005-07.

1082 Vytvytska O, Nagy E, Blüggel M, Meyer HE, Kurzbauer R, Huber LA, Klade CS. (2002). 1083 Identification of vaccine candidate antigens of Staphylococcus aureus by serological proteome 1084 1085 analysis. Proteomics. 2:580-90. DOI: 10.1002/1615-9861(200205)2:5<580::AIDPROT580>3.0.CO;2-G.

Walker J, Jackson HJ, Eggleton DG, Meeusen EN, Wilson MJ, Brandon MR (1994). Identification of a novel antigen from Corynebacterium pseudotuberculosis that protects sheep against caseous lymphadenitis. Infect Immun. 62:2562-2567. DOI: 10.1128/IAI.62.6.25622567.1994.

Wang YY, Ma H, Ding ZC, Yang Y, Wang WH, Zhang HN, Yan JK. (2019). Three-phase partitioning for the direct extraction and separation of bioactive exopolysaccharides from the cultured broth of Phellinus baumii. Int J Biol Macromol. 123:201-209. DOI: 10.1016/j.ijbiomac.2018.11.065.

Weber MM, Faris R. (2018). Subversion of the endocytic and secretory pathways by bacterial effector proteins. Front Cell Dev Biol. 6:1. DOI: 10.3389/fcell.2018.00001.

Weidenmaier C, Peschel A. (2008). Teichoic acids and related cell-wall glycopolymers in Grampositive physiology and host interactions. Nat Rev Microbiol. 6:276-287. DOI: 10.1038/nrmicro1861.

Widjaja M, Harvey KL, Hagemann L, Berry IJ, Jarocki VM, Raymond BBA, Tacchi JL, Gründel A, Steele JR, Padula MP, Charles IG, Dumke R, Djordjevic SP. (2017). Elongation factor Tu is a multifunctional and processed moonlighting protein. Sci Rep. Sep 7:11227. DOI: 10.1038/s41598-017-10644-z.

Williamson LH. (2001). Caseous lymphadenitis in small ruminants. Vet Clin North Am Food Anim Pract. 17:359-3571. DOI: 10.1016/s0749-0720(15)30033-5. 
1108 Windsor PA. (2011). Control of caseous lymphadenitis. Vet Clin North Am Food Anim Pract. 1109 27:193-202. DOI: 10.1016/j.cvfa.2010.10.019.

1110 Xolalpa W, Vallecillo AJ, Lara M, Mendoza-Hernandez G, Comini M, Spallek R, Singh M, 1111 Espitia C. (2007). Identification of novel bacterial plasminogen-binding proteins in the human 1112 pathogen Mycobacterium tuberculosis. Proteomics. 7:3332-33341. DOI:

1113 10.1002/pmic.200600876.

1114 Yan JK, Wang YY, Qiu WY, Ma H, Wang ZB, Wu JY. (2018). Three-phase partitioning as an 1115 elegant and versatile platform applied to nonchromatographic bioseparation processes. Crit Rev 1116 Food Sci Nutr. 58:2416-2431. DOI: 10.1080/10408398.2017.1327418.

1117 Yozwiak ML, Songer JG. (1993). Effect of Corynebacterium pseudotuberculosis phospholipase 1118 D on viability and chemotactic responses of ovine neutrophils. Am J Vet Res. 54:392-397.

1119 Zhao Y, Yokota K, Ayada K, Yamamoto Y, Okada T, Shen L, Oguma K. (2007). Helicobacter 1120 pylori heat-shock protein 60 induces interleukin-8 via a Toll-like receptor (TLR) 2 and mitogen1121 activated protein (MAP) kinase pathway in human monocytes. J Med Microbiol. 56:154-164. 1122 DOI: 10.1099/jmm.0.46882-0. 


\section{Table $\mathbf{1}$ (on next page)}

List of the studies that contributed to characterization of the C. pseudotuberculosis proteome 
Table 1: List of the studies that contributed to characterization of the C. pseudotuberculosis proteome

\begin{tabular}{|c|c|c|c|c|}
\hline $\begin{array}{c}\text { Proteomic } \\
\text { technique/approach }\end{array}$ & Strain/biovar & Sample & Main findings & Reference \\
\hline $\begin{array}{l}\text { SDS-PAGE and } \\
\text { immunoblot }\end{array}$ & ATCC 19410_ovis & $\begin{array}{l}\text { Whole-cell extract and } \\
\text { culture filtrate }\end{array}$ & $\begin{array}{c}\text { Description of protein band patterns produced } C \text {. } \\
\text { pseudotuberculosis and recognized of protein by antibodies } \\
\text { of naturally infected sheep }\end{array}$ & Ellis et al., 1991 \\
\hline $\begin{array}{l}\text { SDS-PAGE and } \\
\text { immunoblot }\end{array}$ & ATCC 19410_ovis & Whole-cell extract & $\begin{array}{l}\text { Identification of } C \text {. pseudotuberculosis antigens using } \\
\text { serum of naturally infected sheep and goats }\end{array}$ & Muckle et al., 1992 \\
\hline $\begin{array}{l}\text { SDS-PAGE and } \\
\text { immunoblot }\end{array}$ & $\begin{array}{c}\text { ATCC 19410_ovis, } \\
\text { ATCC 809_ovis, ATCC } \\
\text { 43927_ovis, ATCC } \\
\text { 43926_ovis, ATCC } \\
\text { 43924_equi, ATCC } \\
\text { 43925_equi, ATCC } \\
\text { PVAMU101_equi }\end{array}$ & $\begin{array}{l}\text { Extracellular proteins and } \\
\text { Whole cells }\end{array}$ & $\begin{array}{c}\text { Description of protein band patterns produced by various } C \text {. } \\
\text { pseudotuberculosis strains. In addition to the recognition of } \\
\text { protein by antibodies of naturally infected goats. }\end{array}$ & Braithwaite et al., 1993 \\
\hline SDS-PAGE & $\begin{array}{l}\text { T1_ovis, T2_ovis and } \\
\text { 1002_ovis }\end{array}$ & Extracellular proteins & $\begin{array}{l}\text { A CDM standardized to the growth of } C . \\
\text { pseudotuberculosis. }\end{array}$ & Moura-Costa et al., 2002 \\
\hline $\begin{array}{l}\text { SDS-PAGE and } \\
\text { immunoblot }\end{array}$ & T1_ovis and 1002_ovis & Extracellular proteins & $\begin{array}{l}\text { The TPP method showed to be suitable to obtain secreted } \\
\text { proteins of } C \text {. pseudotuberculosis. }\end{array}$ & Paule et al., 2004 \\
\hline LC-MSE & $\begin{array}{l}\text { 1002_ovis and } \\
\text { C231_ovis }\end{array}$ & Extracellular proteins & $\begin{array}{c}\text { TPP/LC-MSE is a suitable approach to characterize } \\
\text { extracellular proteins of } C \text {. pseudotuberculosis, and } \\
\text { comparative analysis reveals the production of PLD, CP40, } \\
\text { and CiuA only in C231_ovis. }\end{array}$ & Pacheco et al., 2011 \\
\hline
\end{tabular}




\section{SERPA (2-DE \\ MALDI-TOF/TOF- \\ $\mathrm{MS} / \mathrm{MS}$ )}

\section{LC-MSE}

2-DE MALDI-

TOF/TOF-MS/MS

\begin{abstract}
2D-DIGE MALDI-
TOF/TOF-MS/MS
\end{abstract}

SERPA (2-DE/LC-
MS/MS)

LC-MSE / 2-DE

MALDI-TOF/TOF-

MS/MS

LC-MS/MS 1002_ovis

1002_ovis and $\Delta s i g E$

1002_ovis and

C231_ovis

\section{2_ovis and \\ C231_ovis}

\section{2_ovis and C231_ovis}

$$
\text { 1002_ovis }
$$

C231_ovis and

RLC001_ovis
Extracellular proteins

Identification of six immunoreactive exoproteins (RpfB NIpC/P60, efflux system protein, SIpA, and one unknown function protein)

Extracellular proteins

Extracellular proteins

ar proteins

Whole-cell extract extract
Characterization of the set of extracellular proteins regulated by sigE during nitric oxide exposition.

Detection of PLD only in C231_ovis and identification of 11 new extracellular proteins of $C$. pseudotuberculosis.

Quantitative analysis reveals the modulation of proteins involved in the cell envelope, respiratory metabolism, and proteolysis.

Identification of immune-reactive extracellular proteins

Network of proteins related to resistance and survival of $C$. pseudotuberculosis to nitrosative stress

Thirteen surface proteins of C. pseudotuberculosis were detected exclusively from bacterial shaving in caseous nodules. In addition, 49 host proteins also were detected in infected nodules.
Seyffert et al., 2011

Pacheco et al., 2012

Silva et al., 2013a

Silva et al., 2013b

Seyffert et al., 2014

Silva et al., 2014

Rees et al., 2015a 


\begin{tabular}{|c|c|c|c|}
\hline $\begin{array}{l}\text { Dimethylation } \\
\text { labeling LC-MS/MS } \\
\text { and label-free LC- } \\
\text { MS/MS }\end{array}$ & $\begin{array}{l}\text { C231_ovis, } \\
\text { RLC001_ovis, } \\
\text { RLC002_ovis and } \\
\text { RLC003_ovis }\end{array}$ & Whole-cell extract extract & $\begin{array}{l}\text { Proteins related to hypoxia, nutrient deficiency responses, } \\
\text { and thiopeptide biosynthesis are more induced in field } \\
\text { isolate than reference strain C231_ovis. }\end{array}$ \\
\hline LC-MSE & 1002_ovis & Extracellular proteins & $\begin{array}{l}\text { Bacterial serial passage in a murine model induces the PLD } \\
\text { and CP40 proteins. }\end{array}$ \\
\hline LC-MSE & 258_equi & Extracellular ptoteins & $\begin{array}{l}\text { Iron acquisition proteins are more induced in the } \\
\text { exoproteome of 258_equi recovered from mice spleen. }\end{array}$ \\
\hline LC-MSE & 1002_ovis and 258_equi & Whole-cell extract extract & $\begin{array}{l}\text { Identification of protein strain-specific in 1002_ovis and } \\
\text { 258_equi. }\end{array}$ \\
\hline LC-MS/MS & VD57_ovis & $\begin{array}{l}\text { Membrane-associated } \\
\text { proteins }\end{array}$ & $\begin{array}{l}\text { Bacterial grown in animal serum induce production of } \\
\text { proteins associated with iron uptake and Opp system }\end{array}$ \\
\hline LC-MSE & $\begin{array}{l}\text { CAP3W_ovis and } \\
\text { CAPJ4_ovis }\end{array}$ & Whole-cell extract & $\begin{array}{l}\text { Proteins related to biological processes involved in biofilm } \\
\text { formation, such as quorum sensing, metabolism, and cell } \\
\text { wall components were more abundant in biofilm-forming }\end{array}$ \\
\hline
\end{tabular}

labeling LC-MS/MS

RLC001 ovis,

LCO02_ovis and

RLC003_ovis

strain.
Silva et al., 2017a

Silva et al., 2017b

Silva et al., 2017c

Raynal et al., 2018

De Sá et al., 2021 


\section{Table 2 (on next page)}

Proteins described like moonlight protein detected in the exoproteome and surfaceome of C. pseudotuberculosis 
Table 2: Proteins described like moonlight protein detected in the exoproteome and surfaceome of $C$. pseudotuberculosis

\begin{tabular}{|c|c|c|c|c|c|c|}
\hline Protein name & Reference & $\begin{array}{c}\text { C. pseudotuberculosis } \\
\text { proteome }\end{array}$ & $\begin{array}{c}\text { Canonical Function } \\
\text { and biological } \\
\text { processes }\end{array}$ & $\begin{array}{l}\text { Moonlight } \\
\text { function }\end{array}$ & Microorganism & Reference \\
\hline $\begin{array}{l}\text { Superoxide dismutase } \\
{[\mathrm{Mn}]}\end{array}$ & Silva et al., $2013 a$ & Exoproteome & Antioxidant & Adhesion & $\begin{array}{l}\text { Mycobacterium } \\
\text { avium }\end{array}$ & Reddy et al. (2004) \\
\hline $\begin{array}{l}\text { 6-phosphogluconate } \\
\text { dehydrogenase }\end{array}$ & Silva et al., $2017 a$ & Exoproteome & $\begin{array}{c}\text { Pentose phosphate } \\
\text { pathway }\end{array}$ & Adhesion & $\begin{array}{l}\text { Streptococcus } \\
\text { pneumoniae }\end{array}$ & Daniely et al. (2006) \\
\hline \multirow[t]{7}{*}{ Enolase } & $\begin{array}{l}\text { Silva et al., 2013a; } \\
\text { Rees et al., 2015a, } \\
\text { Silva et al., 2017a }\end{array}$ & $\begin{array}{l}\text { Exoproteome and } \\
\text { Surfaceome }\end{array}$ & Glycolysis pathway & $\begin{array}{l}\text { Plasminogen } \\
\text { binding }\end{array}$ & $\begin{array}{l}\text { Aeromonas } \\
\text { hydrophila }\end{array}$ & Sha et al. (2009) \\
\hline & & & & $\begin{array}{c}\text { Plasminogen } \\
\text { binding }\end{array}$ & $\begin{array}{l}\text { Bifidobacterium } \\
\text { lactis }\end{array}$ & Candela et al. (2009) \\
\hline & & & & $\begin{array}{l}\text { Plasminogen } \\
\text { binding }\end{array}$ & $\begin{array}{l}\text { Borrelia } \\
\text { burgdorferi }\end{array}$ & Floden et al. (2011) \\
\hline & & & & $\begin{array}{c}\text { Binds } \\
\text { plasminogen, } \\
\text { fibronectin and } \\
\text { epithelial cells }\end{array}$ & $\begin{array}{l}\text { Lactobacillus } \\
\text { plantarum }\end{array}$ & Glenting et al. (2013) \\
\hline & & & & $\begin{array}{c}\text { Plasminogen } \\
\text { binding }\end{array}$ & $\begin{array}{l}\text { Neisseria } \\
\text { meningitidis }\end{array}$ & Knaust et al. (2007) \\
\hline & & & & $\begin{array}{l}\text { Plasminogen and } \\
\text { laminin binds }\end{array}$ & $\begin{array}{l}\text { Staphylococcus } \\
\text { aureus }\end{array}$ & $\begin{array}{l}\text { Mölkänen et al. } \\
\text { (2002); Carneiro et al. } \\
\text { (2004) }\end{array}$ \\
\hline & & & & $\begin{array}{l}\text { Plasminogen } \\
\text { binding }\end{array}$ & $\begin{array}{l}\text { Streptococcus } \\
\text { pneumoniae }\end{array}$ & Pancholi et al. (1998) \\
\hline $\begin{array}{l}\text { Glyceraldehyde-3- } \\
\text { phosphate } \\
\text { dehydrogenase } \\
\text { (GAPDH) }\end{array}$ & $\begin{array}{l}\text { Pacheco et al., } \\
\text { 2012; Silva et al., } \\
\text { 2013a; Silva et al., } \\
\text { 2013b; Rees et al., }\end{array}$ & $\begin{array}{l}\text { Exoproteome and } \\
\text { Surfaceome }\end{array}$ & Glycolysis pathway & $\begin{array}{l}\text { Binds } \\
\text { plasminogen, } \\
\text { fibronectin, } \\
\text { mucin and }\end{array}$ & $\begin{array}{l}\text { Lactobacillus } \\
\text { plantarum }\end{array}$ & Glenting et al. (2013) \\
\hline
\end{tabular}


$2015 a$

\section{Phosphoglycerate}

Phosphoglyceromutase kinase

Triosephosphate isomerase

Pacheco et al., 2011; Silva et al., 2013a

Pacheco et al., 2011

Pacheco et al., 2011

\begin{tabular}{cll}
\multicolumn{2}{c}{ epithelial cells } & \\
\hline Fibronectin & Streptococcus & Pancholi et al. (1992 \\
binding protein - & pyogenes & \\
Plasminogen & & \\
binding protein - & \\
Cell signaling & & \\
kinase/ADP & \\
ribosylase - & \\
Neutrophil & & \\
evasion protein & & Matta et al. (2010) \\
\hline Plasminogen & Bacillus & \\
binding & anthracis & \\
\hline Plasminogen & Streptococcus & Bergmann et al. (2004) \\
binding protein / & pneumoniae & \\
Adhesin for &
\end{tabular}

mucin

Exoproteome Glycolysis pathway

Actin and plasminogen

Streptococcus

Boone et al. (2012) plasminogen

\begin{tabular}{cll}
\hline $\begin{array}{c}\text { Plasminogen } \\
\text { binding and } \\
\text { complement } \\
\text { inhibitor }\end{array}$ & $\begin{array}{l}\text { Streptococcus } \\
\text { pneumoniae }\end{array}$ & $\begin{array}{l}\text { Fulde et al. (2014); } \\
\text { Blom et al. (2014) }\end{array}$ \\
\hline Mucin binding & $\begin{array}{l}\text { Bifidobacterium } \\
\text { longum }\end{array}$ & Nishiyama et al. (2020) \\
\hline
\end{tabular}

Exoproteome

Glycolysis pathway

Mucin bindin

Lactobacillus

Pérez Montoro et al.

Plasminogen
binding
Plasminogen
binding
pentosus (2018)

Mycoplasma Gründel et al. (2015)

pneumoniae

Glycolysis pathway binding
Staphylococcus Ikeda et al. (2011) aureus 


\begin{tabular}{|c|c|c|c|c|c|c|}
\hline \multirow[t]{3}{*}{ Chaperone GroEL } & \multirow[t]{3}{*}{ Silva et al., 2013a } & \multirow[t]{3}{*}{ Exoproteome } & \multirow[t]{3}{*}{ Chaperone } & $\begin{array}{l}\text { Adherence- } \\
\text { invasion }\end{array}$ & $\begin{array}{l}\text { Legionella } \\
\text { pneumophila }\end{array}$ & Garduño et al. (1998) \\
\hline & & & & Adhesin & $\begin{array}{l}\text { Lactobacillus } \\
\text { johnsonii }\end{array}$ & Kinoshita et al. (2016) \\
\hline & & & & Adhesin & $\begin{array}{l}\text { Clostridium } \\
\text { difficile }\end{array}$ & $\begin{array}{l}\text { Hennequin et al. } \\
\text { (2001) }\end{array}$ \\
\hline \multirow[t]{3}{*}{$\begin{array}{l}\text { Chaperone protein } \\
\text { DnaK }\end{array}$} & \multirow[t]{3}{*}{$\begin{array}{l}\text { Pacheco et al., } \\
\text { 2012; Silva et al., } \\
\text { 2013a }\end{array}$} & \multirow[t]{3}{*}{ Exoproteome } & \multirow[t]{3}{*}{ Chaperone } & $\begin{array}{l}\text { Plasminogen } \\
\text { binding }\end{array}$ & $\begin{array}{l}\text { Bifidobacterium } \\
\text { lactis }\end{array}$ & Candela et al. (2010) \\
\hline & & & & $\begin{array}{l}\text { Plasminogen } \\
\text { binding }\end{array}$ & $\begin{array}{l}\text { Neisseria } \\
\text { meningitidis }\end{array}$ & Knaust et al. (2007) \\
\hline & & & & $\begin{array}{l}\text { Plasminogen } \\
\text { binding }\end{array}$ & $\begin{array}{l}\text { Mycobacterium } \\
\text { tuberculosis }\end{array}$ & Xolalpa et al. (2007) \\
\hline Peroxiredoxin & $\begin{array}{l}\text { Pacheco et al., } \\
\text { 2011; Silva et al., } \\
\text { 2013a }\end{array}$ & Exoproteome & Antioxidant & $\begin{array}{l}\text { Plasminogen } \\
\text { binding }\end{array}$ & $\begin{array}{l}\text { Neisseria } \\
\text { meningitidis }\end{array}$ & Aljannat et al. (2020) \\
\hline \multirow[t]{5}{*}{ Elongation factor Tu } & \multirow[t]{5}{*}{$\begin{array}{l}\text { Pacheco et al., } \\
\text { 2011; Silva et al., } \\
\text { 2013a }\end{array}$} & \multirow[t]{5}{*}{ Exoproteome } & \multirow[t]{5}{*}{$\begin{array}{c}\text { Translation } \\
\text { elongation factor Tu }\end{array}$} & $\begin{array}{l}\text { Attachment to } \\
\text { human cells and } \\
\text { mucins }\end{array}$ & $\begin{array}{l}\text { Lactobacillus } \\
\text { johnsonii }\end{array}$ & Kinoshita et al. (2016) \\
\hline & & & & $\begin{array}{l}\text { Fibronectin } \\
\text { binding }\end{array}$ & $\begin{array}{l}\text { Mycoplasma } \\
\text { pneumoniae }\end{array}$ & Widjaja et al. (2017) \\
\hline & & & & $\begin{array}{l}\text { Mucin (MUC7)- } \\
\text { binding protein }\end{array}$ & $\begin{array}{l}\text { Streptococcus } \\
\text { gordonii }\end{array}$ & Kesimer et al. (2009) \\
\hline & & & & Binds mucin & $\begin{array}{l}\text { Bifidobacterium } \\
\text { longum }\end{array}$ & Nishiyama et al. (2020) \\
\hline & & & & $\begin{array}{l}\text { Receptor for host } \\
\text { proteins }\end{array}$ & $\begin{array}{l}\text { Pseudomonas } \\
\text { aeruginosa }\end{array}$ & Barbier et al. (2013) \\
\hline Chaperonin GroES & $\begin{array}{c}\text { Pacheco et al., } \\
\text { 2011; Silva et al., } \\
\text { 2013a }\end{array}$ & Exoproteome & Chaperone & $\begin{array}{l}\text { Macrophage } \\
\text { adhesion }\end{array}$ & $\begin{array}{l}\text { Mycobacterium } \\
\text { tuberculosis }\end{array}$ & Hickey et al. (2010) \\
\hline
\end{tabular}

1 
Figure 1

Workflow of the strategy adopted to characterize the C. pseudotuberculosis exoproteome

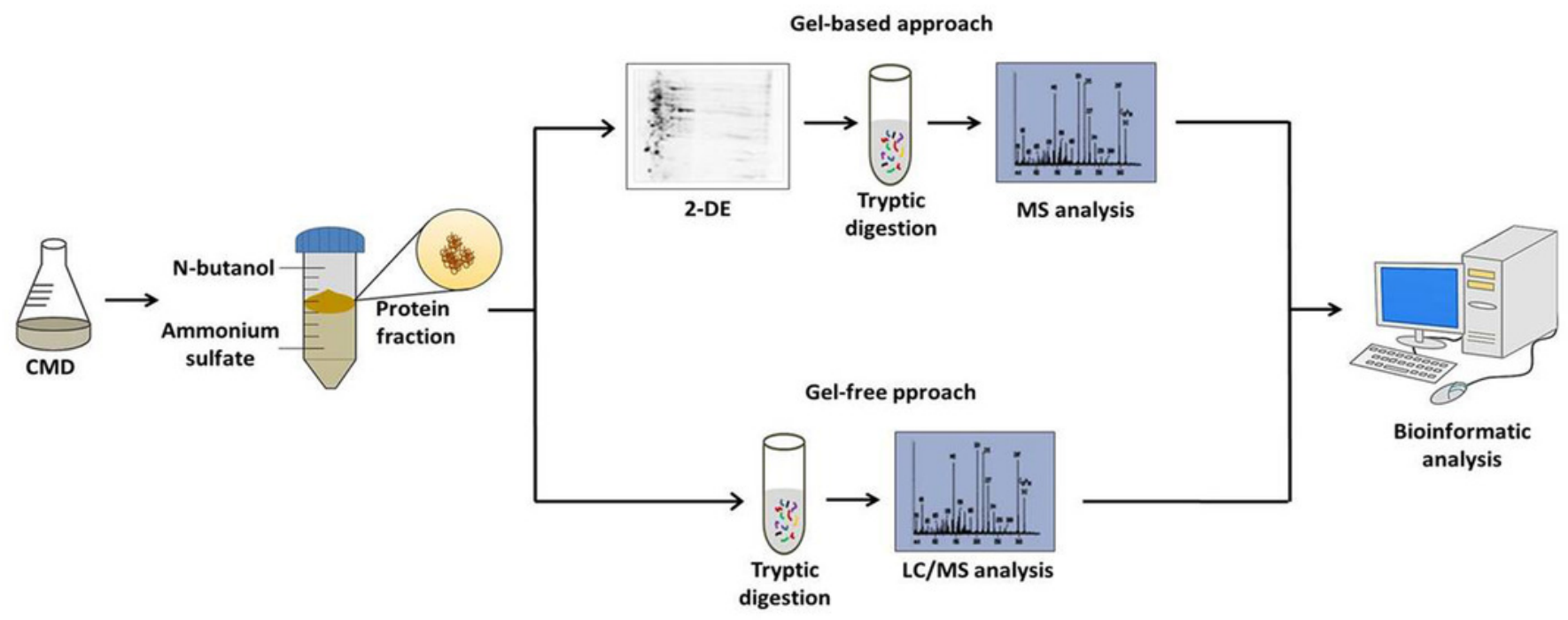

